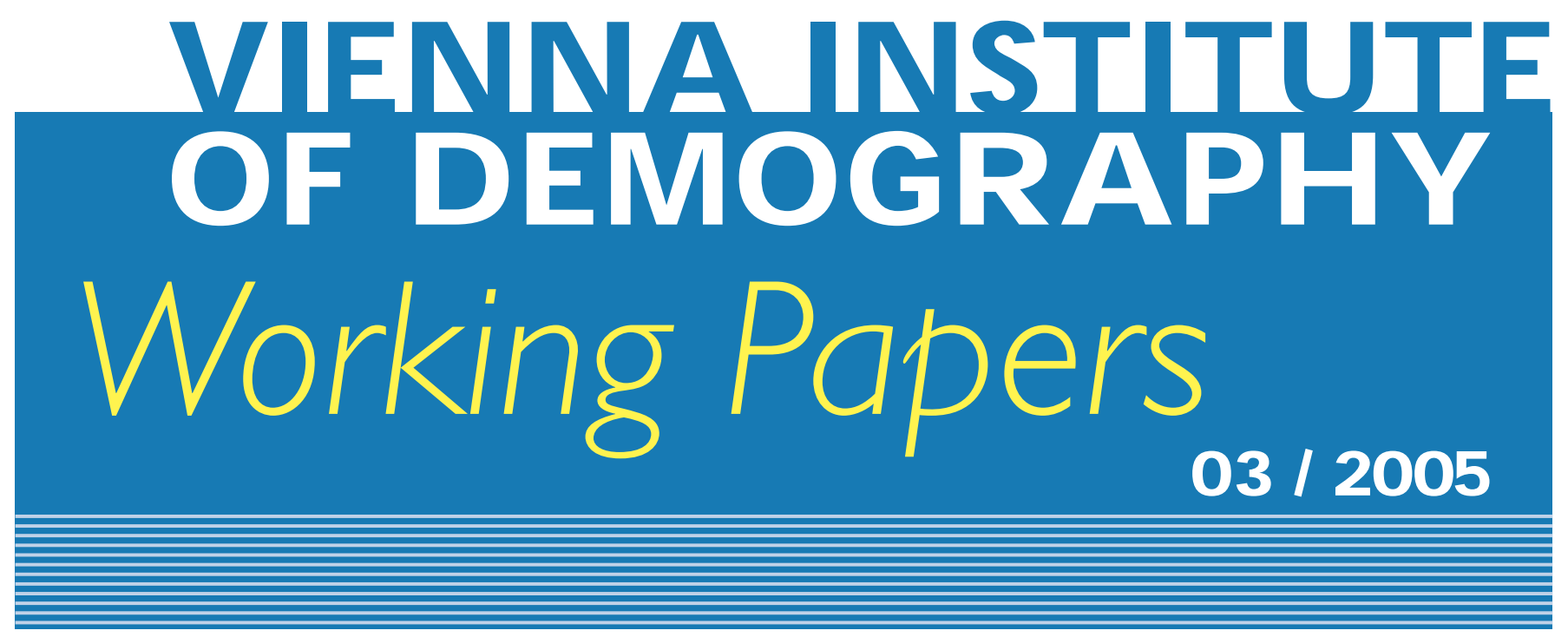

Frank H eiland, Alexia Prskawetz, and W arren C. Sanderson

\title{
Do the M ore-Educated Prefer Smaller Families?
}

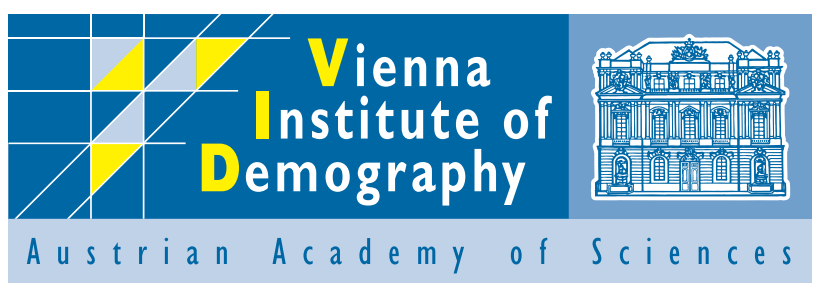

Vienna Institute of D emography

Austrian A cademy of Sciences

Prinz Eugen-Strasse 8-10 · A-1040 Vienna · A ustria

E-Mail: vid@ oeaw.ac.at

W ebsite: www.o eaw.ac.at/vid 


\begin{abstract}
This study investigates the relationship between education and desired family size in Western Europe. Using rich individual-level data from West Germany we find that more-educated men and women are more likely to prefer a family of three (or more) children over a family of two children compared to individuals with average schooling. We also find some evidence that the more-educated are less likely to favor childlessness or the one-child family over having two children. Replication of the analysis with multinational data indicates that this novel relationship holds more broadly in Western Europe. Since higher education is associated with lower realized fertility, we confirm that the gap between desired and actual fertility is largest for the more-educated. We argue that these individuals deserve more attention in the current policy debate since their fertility may be particularly responsive to interventions that help them remove the obstacles to having the family of two or more children that many of them still desire.
\end{abstract}

\title{
Keywords
}

Fertility Preferences, Desired Family Size, Education, West Germany, Western Europe

\section{Authors}

Frank Heiland, Assistant Professor, Center for Demography and Population Health and Department of Economics, Florida State University, Tallahassee, FL 32306-2180, USA.

Alexia Prskawetz, Research group leader and deputy director, Vienna Institute of Demography, Austrian Academy of Sciences, Austria.

Warren C. Sanderson, Professor of Economics, Departments of Economics and History, State University of New York at Stony Brook, US and Visiting Professor, International Institute for Applied Systems Analysis, Laxenburg, Austria.

\section{Acknowledgements}

For valuable comments and suggestions, we would like to thank Wolfgang Lutz, Francesco Billari, Dimiter Philipov, Ike Eberstein, Carl Schmertmann, Woody Carlson, Henriette Engelhardt, Maria Rita Testa, Anne Goujon, and the participants of the session on fertility preferences at the 2005 Meetings of the Population Association of America. Heiland and Prskawetz are indebted to the Max Planck Institute for Demographic Research in Rostock for their hospitality while parts of this project were in progress. Heiland acknowledges financial support from the European Union (RTN project contract number HPRN-CT-2001-00234). 


\title{
Do the more-educated prefer smaller families?
}

\author{
Frank Heiland, Alexia Prskawetz, and Warren C. Sanderson
}

\section{Introduction}

In most developed countries and particularly in Western Europe, total period fertility rates have fallen below replacement level and total cohort fertility rates have confirmed that the average number of children per woman is declining across cohorts (see Frejka and Calot 2001, among others). Consistent with the dramatic decline of fertility in Western Europe, recent survey data on fertility preferences suggest that the desired number of children may be falling across cohorts (Goldstein et al. 2003). Overall, desired family size has, however, remained close to the two-child ideal in most European countries (Lutz 1996, Goldstein et al. 2003) implying a significant, persistent and possibly widening gap between desired and actual number of children. Among West German women, for example, completed cohort fertility has fallen from 2.2 to 1.6 between the 1935 and the 1956 birth cohorts while the desired number of children is estimated to have declined from 2.5 to 2.2 across the same cohorts (see Figure 1).

A better understanding of the characteristics of individuals who desire large families but find themselves unable to realize them is potentially important for the prospects of fertility and may inform public policies. The fertility behavior of individuals who desire more births than they can realize is likely to be more responsive to policy interventions that remove the obstacles and constraints currently in place that prevent them from achieving their desired family size targets. ${ }^{1}$

While one dimension of the gap, observed fertility, has received a lot of attention in the literature,

\footnotetext{
${ }^{1}$ The existence of a gap between desired and realized number of children is interpreted by some as "unmet demand" for children (Chesnais 1996, 2000). We consider the actual number of births as the demand (for children) and take the existence of a gap as evidence for constraints that if removed may lead to more births.
} 
much less research exists on the determinants of desired family size in Western Europe. Specifically, fertility research has identified increases in educational attainment resulting from rising returns to human capital, improved access to the labor market and more effective contraception as a leading cause of fertility postponement and ultimately lower fertility, in particular among women (e.g., Kohler et al. 2002, Kreyenfeld 2002 for West Germany). ${ }^{2}$ Whether a similar negative relationship exists between educational attainment and desired fertility, however, is not known. Understanding the extent to which education shapes family size preferences is important for the prospects of higher fertility in Europe. It testifies to whether low fertility among the more-educated is primarily the result of life course contingencies and structural constraints or whether it is simple a reflection of the desire to have fewer children. It also helps to address whether the downward trend in desired family size may be led by the demographic trends of increasing educational attainment of men and women.

In this study, we analyze the relationship between educational attainment and family size preferences. We present evidence from two large individual-level surveys, one from West Germany in 1988 and 1994/95, and the other covering the EU 15 nations in 2001. In addition to descriptive findings regarding the association between education and family size desire, we examine the effect of education on desired family size in detail using a multivariate approach that controls for other possible determinants of desired fertility. The results reject the idea that the more-educated desire smaller families in West Germany and other parts of Europe. We find evidence that the more-educated prefer larger families compared to individuals with average education and training. The pattern is found across gender and age groups and the positive effect of education on the likelihood of desiring three or more children is robust to multivariate analysis in Western Europe. Since higher education is associated with lower realized fertility, we confirm that the gap between desired and actual fertility is largest among the more-educated and discuss some implications for policy interventions.

\footnotetext{
${ }^{2}$ As illustrated in Figure 1, the share of West German women who attend college has increased across cohorts while completed as well as desired number of children has declined.
} 


\section{Background}

\subsection{Measuring Fertility Preferences}

The literature on fertility preferences in developed countries is broad and has its longest tradition in the United States due to data availability. ${ }^{3}$ Depending on the scope of the study 'fertility preferences' are measured either using an instrument of (i) fertility/birth intention (e.g., "Do you plan to have a(nother) child?"), or on (ii) fertility desire or ideal (e.g., "What is your ideal number of children?"). The key conceptual difference between 'intentions' and 'desires' is that family size desires/ideals measure a person's preferred family size whereas intentions capture an individual's expected or planned fertility choice. Since (planned) fertility choices reflect the individual's ranking of possible family sizes and any constraints that may prevent the person from achieving the highest-ranking family size, 'fertility intentions' can differ substantially from 'fertility desires' in the presence of socio-economic or biological constraints. In other words, instruments that measure 'desired fertility' are most suitable to study 'fertility preferences' itself whereas instruments on 'intentions' are more useful to predict fertility behavior. A concern with family size desires/ideals instruments is that they may reflect societal norms rather than the individual's own preference (cf. Livi Bacci 2001).

The relationship between fertility preferences and fertility behavior has been an area of active research as documented below and preferences continue to play an important role in explanations of the fertility decline (Lesthaeghe and Surkyn 1988, Van de Kaa 2001). In our study, we investigate the role of educational attainment on a person's desired or ideal family size. The instruments for preference in the individual-level data-sets from West Germany and the EU 15 countries measure personal desired and personal ideal family size and hence are well-suited for study of the individual's own family size preference.

\footnotetext{
${ }^{3}$ For a survey of the literature on fertility preferences in developing countries see Pritchett 1994.
} 


\subsection{What Shapes Family Size Preferences?}

Early theories of fertility have taken a static view of family size preferences (Becker 1960, Willis 1973). According to this view individual's fertility preferences are shaped early in life and remain constant throughout the reproductive career. More general theories of fertility preferences adopt a dynamic perspective (Modell, Furstenberg and Hershberg 1976, Hogan 1978, Elder 1985) and emphasize the importance of life course events and constraints (Nambodiri 1983, Westoff and Ryder 1977, Westoff 1981) as well as the role of social interactions (Kohler 2001) in the formation of fertility preferences. While family background factors and early influences of family norms can still play a role in the dynamic view, they may be mediated by major life course events and experiences. In particular, childbearing events have been found to strongly influence fertility preferences (Monnier 1987, Miller and Pasta 1995).

As discussed in more detail in the next section, existing research on the education-preference relationship is limited. Why would we expect desired family size to differ by educational attainment? Since schooling and training foster career opportunities and financial independence, the individuals who acquired higher education may value a family-oriented life style less. In that case, we would expect that the more-educated prefer smaller families. On the other hand, education may increase the individual's ability and confidence to cope with childrearing and hence result in a greater preference for large families. ${ }^{4}$

In addition to descriptive evidence, we employ multivariate analysis to test for an effect of education on preferences using three sets of additional potential determinants of fertility preferences: (1) individual background characteristics such as gender, age, religion, attitudinal measures; (2) family background influences such as parents' educational attainment and the presence of siblings in the family; (3) life course and contemporaneous experiences including marital status and partnership history, actual number of children, health status, household income, labor force status, and residency. ${ }^{5}$ If prefer-

\footnotetext{
${ }^{4}$ Pearlin and Schooler (1978) and Mirowsky (1995) have documented greater psychological coping resources and sense of control among more-educated individuals in the U.S..

${ }^{5}$ We note that due to limitations in the data respondent's partner's or spouse's desired family size cannot be controlled for. There is evidence that spousal preferences have an effect on fertility preferences and actual fertility (e.g., Bumpass and
} 
ences are formed very early in a person's life and remain relatively constant thereafter, then life course experiences including schooling and training should contribute little to preference formation compared to family background factors and other early social influences.

\subsection{Previous Evidence}

Most research on fertility 'intentions' and 'desires' has focused on the determinants of the difference between fertility preferences and realizations in different populations (fertility intentions/expectations: Schoen et al. 1999, Joyce et al. 2002, Quesnel-Vallée and Morgan 2003 (all US), Symeonidou 2000 (Greece), Menniti 2001 (Italy), Noack and Østby 2002 (Norway); desired/ideal family size: Coombs 1979, Thomson et al. 1990 (all US), Löhr 1991, Heiland and Prskawetz 2004 (all West Germany), Van Peer 2002 (9 European countries); fertility intentions and family size desires/ideals: Freedman et al. 1980, Hendershot and Placek 1981 (collective volume), Thornton et al. 1984, Thomson 1997 (all US)). ${ }^{6}$ Multivariate studies of the gap between stated and realized fertility typically include measures of educational attainment. The interpretation of education effects obtained in this way is complicated by the fact that it is unclear whether the estimated effect is the result of correlations that exist between education and preference, between education and the constraints, or both. ${ }^{7}$

Few studies have looked at the effect of education on fertility preferences directly. In an early study, Hirsch et al. (1981) find a positive relationship between educational attainment of the parents or raisers and the desired family size of teenage women in the US. The prospect of below replacement fertility in Europe has increased the interest in fertility preferences here. Using fertility intentions data from Bulgaria and Hungary, Philipov et al. (2004) find no effect of educational attainment on the intention of ever having a first child for those without children but a positive effect on ever having a second child

\footnotetext{
Westoff 1970, Morgan 1985, Thomson et al. 1990, Thomson 1997, Van Peer 2002).

${ }^{6}$ Several authors have raised methodological concerns. The predictive value of preference data has been frequently critiqued (Blake 1966, Ryder 1973, Westoff and Ryder 1977, Ryder 1980, Lee 1980, Ryder 1981, Westoff 1981, Joyce et al. 2002, Walker 2003). Others have investigated the validity and comparability of measures (Morgan 1981, Morgan 1982, Bongaarts 1990, Van Hoorn and Keilman 1997).

${ }^{7}$ It is not surprising then that Van Peer 2002, for example, does not find a consistent pattern of the effect of education on the gap between desired and achieved fertility in FFS data from nine European countries (Austria, Belgium (Flanders), Finland, France, Hungary, Italy, Poland, Spain and Sweden).
} 
for those with one child. Engelhardt (2004) finds a positive but not statistically significant relationship between having the highest postsecondary degree ('Matura') and the total desired number of children among women in Austria. Individual-level evidence from Germany is mostly missing. Using 20 to 29 year old West German men and women from the 1988 wave of the DJI Familiensurvey, Löhr (1991) presents descriptive evidence of a polarization of preferences by the quality of the secondary degree. Among individuals with the more advanced college preparatory high school degree a stronger desire for two or more children as well as for childlessness or the one-child family was found, compared to respondents with only a basic high school degree. ${ }^{8}$

To summarize, the existing empirical evidence is very limited but suggests that there may not be a negative relation between education and fertility intentions and desires. In light of the lack of systematic evidence, Huinink (2001), a prominent observer of the fertility trends of more-educated women in Germany, has concluded that "...- we need much more research on the intention issues - they [moreeducated women] show a fairly high level of fertility intentions and with only a small percentage of women expecting to stay childless over time". We extend previous research by examining the effect of education on fertility desires using individual-level data from West Germany in 1988 and 1994 and the EU 15 countries in 2001. We present descriptive as well as multivariate evidence using the rich German data and we replicate the multivariate analysis in the weaker but more recent multinational data.

\section{Data and methods}

The data for this study were taken from the 1988 and the 1994/95 wave of the West German Familiensurvey of the German Youth Institute (DJI Familiensurvey 1988, 1994/95) and the 2001 Eurobarometer (EUROSTAT 2001). ${ }^{9}$ The West German data are rich in terms of measures and sample size while the Eurobarometer data are more current and enable us to replicate the analysis for West Germany within

\footnotetext{
${ }^{8}$ Using data from East and West German 1961-1972 birth cohorts from the 1992 Family and Fertility Survey, Kreyenfeld (2001) finds that East Germans are more certain that they want children and they want to have their first child earlier than West Germans. At the same time, she finds that East Germans are less likely to want a large family than West Germans.

${ }^{9}$ Unfortunately data from the most recent survey round (DJI Familiensurvey 2000) cannot be used in this study since the question on desired number of children does not compare to the earlier waves.
} 
the EU 15 countries.

\subsection{West German Data}

The first wave of the DJI Familiensurvey gathered data on 10,043 individuals from a random sample of German citizens of age 18 to 55 in 1988 who resided in West German households. The sample obtained during the 1994/95 wave contains 6,999 German citizens of ages 18 to 61 who resided in West Germany. 4,997 of the respondents in the second wave are individuals who were also interviewed in the first wave while the remaining 2,002 respondents were randomly sampled from the West German 18 to 30 year old residence population. A comparison to German census data has shown that men are slightly underrepresented in both surveys. In the first survey singles are under-represented whereas they are slightly over-represented among the newly sampled 18 to 30 year-olds. Among individuals interviewed for the second time in 1994/95, women and married individuals continue to be over-represented. ${ }^{10}$ The overrepresentation of women is not a major concern since we conduct our analysis separately for men and women. The sample used in the multivariate analysis below pools the samples from the two waves. To account for potential systematic variation due to attrition of individuals who are part of the longitudinal study, we include a binary indicator to control for individuals who are in both survey waves in addition to an indicator for survey year. ${ }^{11}$

To obtain a sample of individuals with a more homogenous parental background we only included individuals who grew up with at least one parent (excludes 511 initial respondents or $3 \%) .{ }^{12}$ In addition the sample excludes cases with missing values for desired children (809 initial respondents or 4.7\%), educational attainment or training (18), health status (30), labor force status (116), actual number of children (2), and traditional values (112). The final sample consists of 8,616 women and 6,913 men.

\footnotetext{
${ }^{10}$ The details on the sample construction and the comparisons to census data are documented in Bender et al. (1996).

${ }^{11}$ In the multivariate results the standard errors are corrected for clustering to account for repeated observations for individuals who are interviewed in both waves. In additional analyzes using (a) only one occurrence for panel members and (b) only the members of the panel we found qualitatively similar results to those reported here based on the full sample. These results are available from the authors on request.

${ }^{12}$ We also conducted the analysis with the full sample and find qualitatively similar results. These results are available from the authors on request.
} 
Table 1 presents the definitions of the variables and the corresponding summary statistics in the sample of all women and all men and for the subsamples of women in their prime reproductive ages (age 18-35; column 3) and in the 1994 wave (column 4). The measures used in the analysis are discussed in detail in the following sections.

\section{Measure of Family Size Preference}

In both waves of the survey the total number of desired children can be computed for every respondent. In the 1994/95 wave all respondents were asked: Q20(1994/95). If it was entirely up to you, how many children in total would you like to have or liked to have had? The answers are coded on a scale with a minimum of zero and a maximum of four or more children. ${ }^{13}$ In the 1988 wave of the survey the same question was only given to respondents who either had children at the time of the interview ("yes" on Q8(1988)) or those without children who answered "yes" or "depends" to the following question: Q9(1988). Would you like to have children or would you have liked to have children?. Based on the answers to this set of questions in 1988 and question Q20(1994/95) in 1994/95, we generated the variable 'Desired' (cf. Table 1) with scale "none", "one", "two", "three" and "four or more". For the 1988 round we classified individuals who answered "no" in $Q 9(1988)$ as "none". ${ }^{4}$

The dependent variable measures the individual's own preference for family size and is based on a question that explicitly invites individuals to answer for themselves ("if it was entirely up to you"). ${ }^{15}$ Other surveys such as the 2001 Eurobarometer (EUROSTAT 2001) provide a similar measure of personal desired family size based on the instrument: "personal ideal number of children". We will attempt to replicate the analysis of fertility preferences in West Germany using the Eurobarometer data below.

\footnotetext{
${ }^{13}$ Comparison with a similar measure in the 2001 Eurobarometer indicates that this data limitation of a cut-off point at four children is marginal since only $1 \%$ of the respondents reported personal ideal family size above four. The maximum family size reported in the Eurobarometer for West Germany is seven children.

${ }^{14}$ Morgan 1981, 1982 suggests that respondents who answer "don't know" to questions relating to fertility intentions are an important group that should not be discarded. Unfortunately, in the DJI Familiensurvey a distinction between "don't know" and missing for other reasons in Q19(1988)/20(1994/95) cannot be made. Hence, we do not include this group in our analysis.

${ }^{15}$ As stated above respondents without children answered the question $Q 9$ (1988) which does not make that qualification. We do not expect that this lead-in question causes measurement error in our dependent variable since respondents affected by the qualification would likely be in the "depends" category and hence also answer Q19(1988). In any case, measurement error of this type would be accounted for by the survey year dummy in the analysis below.
} 
As shown in Table 1 the two child family is the most frequently desired family size. In our sample the average desired number of children is 2.2 for women and 2 for men. Only between 5 and $7 \%$ of the respondents state childlessness as their ideal, and only $10 \%$ desire a one child family. More than half of the respondents prefer the two child family, about $20 \%$ desire three children and between 6 and $11 \%$ desire four or more children. Table 1 illustrates the decline in desired fertility. The average number of children for 18-35 year old women is 2.12 compared to 2.21 for all women (age 18-61). A decomposition by desired parity shows that this is the result of a slight increase in preference for being childless and having two children at the expense of a three child (or more) family. There is no evidence of systematic differences in fertility preference between the two survey waves. The desired number of children and its distribution for the women in 1994 differ only marginally from the overall averages.

\section{Educational Attainment and Other Explanatory Factors}

We constructed six binary indicators to measure different levels of completed education at the time of the interview: (1) no high school degree, (2) lowest or middle track high school degree ('Volks-/Hauptschule' or 'Realschule'), (3) lowest or middle track high school degree with job training/apprenticeship ('Lehre', 'Berufsfachschule', 'Volontariat', 'Laufbahnprüfung', or equivalent), (4) college preparatory (college track) high school degree ('Fachhochschulreife' or 'Hochschulreife'), (5) college preparatory high school degree with training, (6) and college degree or higher ('Fachhochschule', 'Universität' or equivalent). The ranking is based on the level of general schooling (basic secondary=ISCED2A, upper secondary=ISCED3A, tertiary/college=ISCED5A/5B/6) differentiated by additional vocational or job training programs. ${ }^{16}$ For individuals who were still participating in a program at the time of the interview (about 14\% of women in 18-35 age group) we code the highest completed attainment at that time and control for non-completion via the labor force status indicator 'In School'.

The most common educational attainment in the data is the combination of basic high school degree

\footnotetext{
${ }^{16}$ The ISCED codes stand for the education attained according to the International Standard Classification of Education. For a helpful summary of the German education system see: http://www.ed.gov/pubs/GermanCaseStudy/chapter1a.html.
} 
and a job training program. The share of women in this category is $57 \%$ compared to $60 \%$ for men. On average men have a slightly higher educational attainment than women. We see that $20 \%$ of the women stopped acquiring education after obtaining a basic high school diploma compared to only $9 \%$ of the men. About $2 \%$ of the respondents report that they have no high school degree at all. ${ }^{17} 15 \%$ of men graduated from college compared to $9 \%$ of women. For more recent cohorts the fraction obtaining higher educational attainment is rising and the educational gap between men and women is narrowing (Table 1, column 1 vs. column 4).

To distinguish the effect of education of the respondent from influences that are transmitted through the parents, we account for the educational attainment of the respondent's parents in the multivariate analysis. The measures of parents' attainment are constructed similar to the measures for the respondent and are described in Table 1.

To account for realized parity at the time of the interview, we use a measure of the number of children of a respondent that reflects biological and non-biological (step, adopted and foster) children. ${ }^{18}$ The fraction of non-biological children of all children in the sample is about $4 \%$ (3\% step, $0.5 \%$ adopted, $0.5 \%$ foster). We replicated the analysis for the measure using biological children only and did not find noteworthy differences. ${ }^{19}$

We find that $28 \%$ of the women are childless and $23 \%$ have one child. One in three women has two children and $16 \%$ have more than two. Women who are in their prime reproductive ages have not yet completed their fertility, hence the distribution is shifted towards lower parity. In the estimation we investigate the sensitivity of the effect of actual on desired family size by controlling for respondents' age and by estimating the relationships for different age groups separately. The descriptives also show that women have more children than men, which is expected since the average age of men and women

\footnotetext{
${ }^{17}$ This is consistent with the German Mikrozensus where $2.2 \%$ of respondents 15 and older who are not currently enrolled report that they did not obtain a high school degree in 1996.

${ }^{18}$ Actual family size is measured in the survey based on the lead-in question, $Q 8(1988) / Q 8(1994 / 95)$. Do you or did you have children? I am interested in your own, step, foster and adopted children as well as the children of your partner, those who live with you, and the follow-up question: Q10(1988)/Q9(1994/95). How many children do you have? Please also include in your count children that no longer live in your household or are no longer alive.

${ }^{19}$ The estimated effects of education on desired fertility reported were almost identical. The results are available from the authors upon request.
} 
is similar in the survey while the mean age at childbirth is lower for women than men (e.g., Bytheway 1981).

In the multivariate analysis below, we also control for respondents' age. It may proxy for otherwise uncontrolled-for life course experiences that are correlated with age and absorbs potential cohort effects. $^{20}$ We also include a binary indicator for whether or not the respondent was interviewed in the first survey year ('Surv 88'). It accounts for systematic variation between the survey waves such as potential differences in survey procedures or period effects that might otherwise be captured by the age measures. Additional factors that may exercise an independent effect on preferences considered in the multivariate analysis are the number of siblings, broken home experience, income, labor force status, marital and relationship status and history, religion, health status, scales for materialistic (Inglehart scale) and traditional views. Explanations of these variables and sample descriptives are given in Table 1.

\subsection{EU 15 Country Data}

To examine whether the relationship between education and desired family size also holds more broadly in Western Europe, we also present multivariate evidence from the 2001 Eurobarometer (EUROSTAT 2001). This data-set contains individual-level information on a representative sample of approximately 1,000 respondents for each of the countries ${ }^{21}$ of the EU 15 (West Germany, East Germany, Austria, Finland, Denmark, Belgium, Luxembourg, France, Greece, Italy, Spain, Ireland, UK, Netherlands, Portugal, Sweden). The survey allows us to conduct a comparative analysis of fertility preferences in the EU-15 countries since all respondents are asked the same set of background questions and a question about their personal ideal number of children that is closest to the one we use above: $Q 61$. And for you personally, what would be the ideal number of children you would like to have or would

\footnotetext{
${ }^{20}$ For example older respondents may report higher desired number of children than younger ones since they are now more aware of the potential benefits of having children. One would need data on the same age group(s) over time to clearly identify cohort effects independently of life cycle or age effects. This difficulty in identifying cohort effects is common to all preference studies using a single cross-section but one finds that it is rarely acknowledged.

${ }^{21}$ The populations of East and West Germany are sampled separately.
} 
like to have had? $?^{22,23}$

The drawbacks of these data are that only a few explanatory factors are available and the measure of education varies from the data set analyzed above. Unlike in the DJI Familiensurvey information on family background factors (parent's education, siblings, broken home), attitudes, belief, unemployment, is not available in the Eurobarometer. Moreover, the survey asks for the respondent's age when full-time education stopped instead of his or her completed educational programs.

Nevertheless the data enable a partial replication of the analysis for West Germany. We construct the categories of educational attainment 'no upper secondary', 'completion of upper secondary', '(some) first stage tertiary education', or 'second stage tertiary education (advanced research qualification) completed' by relating the survey information on the age when full-time education stopped to each country's typical entry age for upper secondary programs (ISCED3A) and second stage tertiary programs (ISCED6) from the 1997 International Standard Classification of Education (ISCED-1997) report. The most frequent attainment is the lowest classification which roughly corresponds to the basic high school or less education under the German system. In the analysis below, we also control for country/region fixed effects and a similar but less detailed set of socio-economic measures as available in the West German data.

\subsection{Methods}

We present descriptive and multivariate results from the West German data and replicate the multivariate results using data from the EU 15 nations. The descriptive findings provide an illustration of the pattern between educational attainment and family size preferences. The multivariate helps to explore the origin and robustness of the correlations between educational attainment and desired number of children suggested by the aggregate pattern.

In the multivariate analysis, we model individual's desired family size as the outcome of a Multinomial Logit (MNL) discrete choice problem (Theil 1969, 1970, McFadden 1974). This modelling

\footnotetext{
${ }^{22}$ This question follows a question on the ideal number of children in general.

${ }^{23} \mathrm{~A}$ detailed discussion of the data can be found in Goldstein et al. 2003.
} 
strategy is motivated by the idea that family size preferences correspond to distinct family type categories (or life styles). The advantage of the MNL model is that it allows the effect of the covariates on the desired number of children to vary by family type. In particular, using this approach we allow for the possibility that education may have a positive effect on both the probability of desiring childlessness, and on the probability of desiring three or more children relative to desiring two children. ${ }^{24} \mathrm{We}$ consider a model with four desired family size outcomes $(d)$ : no children $(d=0)$, one child $(d=1)$, two children $(d=2)$, or three or more children $(d=3) .{ }^{25}$

We will present the empirical results using the complementary odds-ratio and the total probability form of the MNL model. Following standard procedure, we use the most frequent category, i.e. the two child family $(\mathrm{d}=2)$, as reference or base category for the odds-ratios. The probability that family size type $j(j \varepsilon\{0,1,3\})$ is chosen takes the following form

$$
P(d=j \mid x, \beta)=\exp \left(x \beta_{j}\right) /\left[1+\sum_{h \varepsilon\{0,1,3\}} \exp \left(x \beta_{h}\right)\right], \quad j=0,1,3
$$

where $x$ is a set of explanatory variables and $\beta_{j}$ is the coefficient vector associated with preference type $j$. Since the response probabilities must sum to unity, for identification the probability of the base category $(j=2)$ is normalized to

$$
P(d=2 \mid x, \beta)=1 /\left[1+\sum_{h \varepsilon\{0,1,3\}} \exp \left(x \beta_{h}\right)\right]
$$

To interpret the effect of a change in any covariate, $x_{k}$, on desired family size, we first note that the

\footnotetext{
${ }^{24}$ For example, the distribution of actual fertility by parity shows more clustering at childlessness for more-educated women in several European populations including West Germany (Huinink 2001, Dorbritz 2003). Descriptive evidence has suggested that fertility preferences of West German women also shows a pattern of polarization by education (Löhr 1991). Any estimation strategy that uses desired family size as a continuous or ordinal measure would impose an undesirable structure in the presence of such non-linear effects of education on preferences.

${ }^{25} \mathrm{We}$ also conducted the analysis using five family size types: $0=$ childless, $1=$ one child, $2=$ two children, $3=$ three children, $4=$ four or more children. Since this more general specification did not appear to shed much additional light on the determinants on the upper desired parities but makes the exposition more difficult, we decided to report the specification based on four family types only. However, the results are available from the authors on request.
} 
$\log$-odds-ratio is defined by

$$
\ln \frac{P(d=j \mid x, \beta)}{P(d=2 \mid x, \beta)}=x \beta_{j}, \quad j=0,1,3
$$

From expression (3) it is easy to see that the change in the log-probability ratio due to a one unit change in the explanatory variable $x_{k}$ is $\beta_{j, k}$. Hence, a positive estimate $\beta_{j, k}$ implies an increasing relationship between $x_{k}$ and the log-odds of having family size ideal $d=j$ relative to the base category of the two-child family ideal. Also, this effect is greater the larger the coefficient.

We note that in the MNL model the magnitude and even the direction of a change in a covariate can depend on the remaining covariates. To illustrate the magnitude of the effects of educational attainment on desired family size we present the predicted distributions of desired family size assuming that all individuals have the same educational attainment and using the individual data for all other covariates.

A key property of the MNL model is that the outcome categories satisfy Independence of Irrelevant Alternatives (IIA). IIA requires that the exclusion of alternative categories does not change the effect that a covariate has on the odds-ratio of a category. In our context, it means, for example, that we assume that the effect of educational attainment on the chances of favoring the one child over the two child family is the same regardless of whether or not desiring childlessness or the three-or-more child family is included in the model (cf. expression (3)). Based on Hausman tests (cf. Hausman and McFadden 1984) we found no evidence that the IIA assumption is violated in our data. ${ }^{26}$

A difficulty in estimation arises if desired fertility affects realized family size directly. The estimated effect of having children on desired family size would overstate any independent positive effect that childbearing and rearing might have. In that case realized fertility should be a good predictor of desired family size and hence strongly influence the estimated effects of the other covariates. In other words the effects of other variables may not be robust to specifications with and without accounting for realized number of children. To investigate this aspect, we report estimated effects for specifications with and

\footnotetext{
${ }^{26}$ For example, we investigated the validity of the IIA assumption in the West German data by testing for equality of the effects on the risk of favoring the one child family over the two child family using estimates from the full model and a model that excludes the childless and three-or-more categories. In the pooled sample of women the $\chi^{2}$ distributed test statistic was 42.8 which falls short of the critical value of 82.53 that corresponds to the $5 \%$ significance level (given 63 degrees of freedoms). As a result the null hypothesis of equality (validity of IIA) could not be rejected. Additional results are available from the authors on request.
} 
without controls for realized family size. We note that these differences are expected to be particularly strong for respondents who have completed their fertility. Hence we only present estimates by age groups. $^{27}$

\section{Results}

\subsection{Descriptive Results}

Table 2 displays the average desired number of children by educational attainment. The averages suggest that better-educated men and women often desire more children on average than the lesseducated. For example, the average desired family size for women of ages 36 to 45 who attained a college-track high school degree or more education (additional training and/or college) is more than 2.25 compared to 2.16 for women with only a high school degree and training. For older cohorts the effect is even stronger. Figure 2 shows the distribution of family size types by main educational groups. About $40 \%$ of all college-educated women would like to have a family of three or more children compared to only $30 \%$ for women in the largest educational attainment group (basic high school degree, including those with training). For women with college track high school education (including those with training) that figure is $33.2 \%$. For men this difference is almost 12 percentage points. While there is a significant fraction of more-educated women who desire three or more children, the aggregates in Figure 2 also indicate an elevated fraction desiring childlessness ( $8 \%$ for college track or higher vs. $4-5 \%$ for less-educated). This is consistent with the descriptive findings by Löhr (1991) and supports our use of Multinomial Logits that capture a possibly non-linear relationship between

\footnotetext{
${ }^{27}$ Identification of the effect of having children on desired family size is a different issue. If actual fertility is determined by desired fertility or the same (unobserved) characteristics as desired fertility then it is potentially statistically endogeneous and its coefficient needs to be interpreted with caution. For example, women with above-average, but unobserved, preferences for large families are likely to have higher completed fertility as a result. In that case the estimated (positive) effect of realized family size on the odds of desiring a large family overstates any true underlying causal effect that experiencing a(nother) child may exercise on family size preferences. However, the controls for family background and attitudes such as education of the parents, number of siblings, religious orientation, gender role and political attitudes proxy for familyrelated preferences and tastes thereby helping to purge the coefficients of potentially endogeneous variables such as the existing number of children of omitted variable bias (cf. McCallum 1972).
} 


\subsection{Multivariate Results}

\subsubsection{West Germany}

Table 3 reports the estimated MNL education effects for women by age groups on the log-odds ratios of desired family size. The results are reported not controlling for actual number of children (columns 1-3) and controlling for it (columns 4-6) to assess the robustness of the effects to the specification. The reported standard errors are robust using a Huber-White variance estimator that accounts for clustering due to individuals who are in both survey waves. The comparable specifications for men are presented in Table $5 .^{28}$

As discussed above the reference category for the choice probabilities is the two-child family size ideal, and the coefficients are the effects of unit changes on the log-odds of favoring childlessness or the one child over the two child family (columns titled '0' or 1') and on the odds of favoring a family of more than two children over the two child family (columns titled ' $3,4+$ '). The reference for the education effect is the most common attainment, i.e. an individual with basic high school diploma and job training ('HS+Training'). ${ }^{29,30}$

To illustrate the magnitude of the education categories, the effect of unit changes on the predicted probability of each desired family size are presented in Table 4 for women and in Table 6 for men. The predictions are based on the estimates from models with control variables. ${ }^{31}$

\footnotetext{
${ }^{28} \mathrm{We}$ only report the estimates of the education effects. The full tables are presented in a working paper version of this manuscript made available by the authors on request.

${ }^{29}$ The reference categories for the other variables are individuals with strong post-materialistic views ('PPM'), who are currently employed, have a monthly household-level income between 2,000 and 4,000 Deutschmarks, have one child (where applicable), are married and living together ('Marriedt'), have parents with a high school diploma and job training, and have no siblings. We control for missing cases for income, Inglehart scale, parents' education, and siblings. We also account for potential survey year effects and for systematic attrition by including a binary indicator for individuals who are member of the panel and did not attrite. In both cases we do not find strong evidence of such effects.

${ }^{30}$ We obtained qualitatively similar results to those reported here using basic high school and training and lower attainments combines as reference category.

${ }^{31}$ We conducted further sensitivity analysis to determine the robustness of the education pattern. We obtained estimates from the sample for the first wave and the second wave of the survey separately. The magnitude of the effects of higher education on desired fertility was essentially unchanged. We also investigated the sensitivity of the results to the definition of the age groups and the results did not display dramatic changes as the cut-off points varied. As mentioned above, we
} 
The models fit the data moderately well with (pseudo) coefficients of determinations, $R^{2}$, ranging from 0.06 to 0.27 . The best fits are obtained in models that control for actual number of children by order. In the latter case most effects of the remaining covariates are not dramatically changed suggesting that these factors have strong underlying effects on preferences. Overall, we find that both background and contemporaneous factors play a role in shaping fertility preferences supporting the idea that preferences are responsive to life course events.

\section{Women's Desire for three or more Children}

The results show that on average women with higher educational attainment prefer the three-or-morechild-family over the two child family. For example, a college educated women in the 36-45 age group is about $60 \%^{32}$ more likely to favor three or more children over two children compared to a women with the reference education of basic high school degree and job training (Table 3, columns 3 and 6). The effect of college degree on this odds ratio is of even larger for younger as well as older women. The estimates are statistically significant different from zero across age groups and for specifications with and without controls for actual number of children. Women with college preparatory degree and training are also more likely to favor the large family over the two-child family than women with less schooling but the coefficients are not individually significant except for women younger than 36 .

The magnitude of the effect of education on the desire for large families is best illustrated by looking at predicted probabilities. Columns 4 and 8 in Table 4 report the predicted fraction of women in the respective age and educational group that desire three or more children. The predictions are obtained from the fitted model using the actual characteristics of each individual for all variables except from educational attainment. The resulting partial effects of education show a strong positive relationship between final degree/training and the desire to have at least three children. If all women had a basic

replicated the analysis using the biological children only and did not find noteworthy differences. Moreover, we investigated how the effect changes when certain control variables were dropped from the equation. Most importantly, we estimated the relationship without the respondent's parents' educational attainment and found that the education effects become slightly stronger.

${ }^{32}$ This change in the odds-ratio is obtained from exponentiating the reported log-odds coefficients and subtracting unity: $e^{0.456}-1=0.58$ or $58 \%$. In general we are computing $\frac{P\left(d=j \mid x_{k}=1, \beta\right)}{P\left(d=2 \mid x_{k}=1, \beta\right)}-\frac{P\left(d=j \mid x_{k}=0, \beta\right)}{P\left(d=2 \mid x_{k}=0, \beta\right)}=e^{1 \cdot \beta_{j, k}}-e^{0 \cdot \beta_{j, k}}=e^{\beta_{j, k}}-1$ using Expression (3) to determine the change in the odds-ratio $j$ over 2 due to $x_{k}$. 
high school degree and job training (the most frequent attainment in the sample) about $25 \%$ of the 18 to 35 year old would desire three or more children. If all women in that age group had a college degree then holding everything else constant almost $37 \%$ would desire such large families.

For the most part the effects are monotone within each age group so that the predicted differences between not having any high school degree and being a college graduate are found to be substantial. The ranges are somewhat smaller if we do not control for the actual number of children. It is interesting to note that with up to 20 percentage points difference (controlling for children), the differences between the extremes is largest for the more mature women (46 to 61), a group that must have completed fertility already. The results suggest that while the effect of education on the desire to have a large family is strong within each age group it may become smaller across cohorts.

\section{Women's Desire for Childlessness and One-Child Family}

We now turn to the desire for family types with fewer children than the two-child family, i.e. childlessness and the one-child family. About $10 \%$ of the women in the sample desire the one-child family arrangement and 5\% wish to remain childless. Comparing the one-child family to the two-child family we find that the odds of favoring the one-child family over the two-child family are smaller for women with more education. While the individual coefficients are only statistically significant for the youngest women the direction of the effects is consistent with a positive association between education and family size. The predicted probability distribution confirms this interpretation: the fraction of women who desire the one-child family tends to be higher for lower-educated women. For example, if all women in the 46 to 61 age group were college-educated 5\% would desire only one child compared to $10 \%$ if all women had only a basic high school degree.

The estimated effect of education on the preference for childlessness over the two-child-family mostly shows the expected pattern: for attainments below (above) the reference education category the effects on the log-odds ratios are positive (negative) indicating that the desire for childlessness is more (less) common among less (more) educated women then more (less) educated women. However, some noteworthy exceptions exist for women who just completed or are about to complete their fertility 
(36-45 group). The estimates for college preparatory school with training and for college are positive (Table 3, columns 1 and 4). While the estimates are not statistically different from zero, which may be due to noisy data, the sign suggests that the desire for childlessness is higher for women with high educational attainment compared to women with a basic high school degree and training. The predicted family size distribution confirms that for the youngest and the oldest cohorts in the sample education and childlessness are negatively associated but for the intermediate age group the relationship appears to be u-shaped. Apart from the effect on childlessness for this age group there is no evidence of a polarization among better-educated women. The polarization towards the end of the reproductive span is likely the result of increased heterogeneity within educational groups as women with career jobs try to cope with increasingly demanding trade-offs between family life and career.

\section{Men's Family Size Preferences}

Interestingly, we find the same pattern of the educational attainment effect on family size preference for men that we saw for women. For the discussion we recall that the distribution of desired number of children is different for men. Specifically, the 'average' male respondent is more likely to desire no, one or two children - at the expense of three or more children - than the average woman in the sample (e.g., Table 6, row 1).

Men who obtained a college degree or graduated from a college preparatory high school with or without training are less likely to favor childlessness and more likely to favor three or more children than those with lower attainments. As for women, the effect on larger family size is particularly visible for college-educated men: predictions show that these men are around 10 percentage points more likely to favor three or more children than men with a basic high school degree and training (the reference group). The pattern is less visible for the effects on the preference for a large family for men between age 36 and 45. However, it is found also for this group if one only considers categories two children or more versus less than two. 


\subsubsection{Countries of the EU-15}

Table 7 shows the multinomial logit coefficients of the effect of educational attainment on the personal ideal number of children for 5,949 women in different age groups from the EU-15. The reference category for the education effects in Table 7 is the lowest attainment, no completion of upper secondary education. The reference category is also the most common attainment in the sample (column 1). Within the data limitations in the Eurobarometer we attempted to make the specification comparable to Table 3. The many positive and statistically significant coefficients of higher educational attainments (ISCED3A or higher) on the odds of favoring three or more children over the two-child family suggest that on average better-educated women in the EU-15 are more likely to consider a large family as personal ideal than those without upper secondary education. Also consistent with a positive effect of education on family size ideal is that the EU-15 women with higher educational attainment are more likely to favor the two-child ideal over the one-child ideal. However, this effect is only statistically significant for older women. Finally, for age groups 18 to 35 and 36 to 45 we find mostly positive effects of higher education on the odds of considering childlessness ideal relative to two children. While the estimates are small and not statistically significant they may reflect some polarization of fertility preferences among higher educated women. ${ }^{33}$

\section{Discussion}

Since schooling and training provide career opportunities and financial independence, one might conjecture that more-educated men and women desire a less family-oriented life style. Descriptive and multivariate evidence from two large individual-level data sets show that this is not the case in Western Europe.

Evidence from West Germany rejects the idea that education might have a negative association

\footnotetext{
${ }^{33}$ To investigate the robustness of the pattern in Table 7 we also looked at results from models using a measure of the years of full-time schooling. Using this continuous variable and its square we found the same positive association between education and a family size ideal of three or more children. The models for the men of the EU-15 show a similar pattern. These additional results are available from the authors upon request.
} 
with the desired number of children. On the contrary, we find some evidence that higher educational attainment is associated with an elevated desire to have a large family in West Germany. Controlling for various background and contemporaneous factors, including the realized number of children, we find the effect of education on desired family size to be remarkably consistent. It is found for women and men alike and across age groups but appears to have weakened for more recent cohorts. In particular we document a substantially greater desire for the family of three-or-more children among graduates from college preparatory high schools and college graduates compared to those with lower educational attainment.

An analysis of this relationship in recent survey data from the EU 15 also rejects the idea that the more-educated prefer smaller families. While the multinational results are not readily comparable to those obtained from the richer West German data due to some data limitations, our findings indicate that the positive relationship between educational attainment and family size preferences found in West Germany may hold more broadly in Western Europe.

The finding that more-educated Western Europeans are more likely to desire three-or-more children than those with average educational attainment is novel and our interpretation will remain tentative. The positive relation may reflect a direct effect of the education experience on preferences: additional formal education may yield greater confidence in one's ability to cope with family stress (cf. Pearlin and Schooler 1978 and Mirowsky 1995). It may also result from common underlying factors that are otherwise not accounted for: Individuals who spend more time in formal education may be inherently more willing to wait for rewards or may be inherently more confident about their abilities as parents. As a result, they may have a greater tolerance for raising children. Further, education may capture differences in the ability to afford a larger family if the income measures in the multivariate analysis only imperfectly account for differences in resources by education.

In a recently issued policy statement on demographic change, the European Commission (2005, p. 2) concludes that "Europeans would like to have more children. But they are discouraged from doing so by all kinds of problems that limit their freedom of choice, ...". Our findings that the bettereducated desire larger families but realize smaller ones indicates that more-educated Europeans may 
face particular hurdles. They may be subjected to constraints that make the realization of the kind of family life that they desire difficult. For example, in West Germany the magnitude of the gap between desired and realized fertility can be substantial as illustrated in Table 2 for age groups that are about to complete or have completed fertility. More than half of the college-educated women in the age group 46 to 61 desire more children than they realized, compared to $24 \%(36 \%)$ among women with a basic high school degree (high school degree and job training).

At a time when many industrialized societies, and Germany in particular, are beginning to face the social and economic consequences of sustained below replacement fertility, this study identifies a key demographic group that on average desires two or more children while realizing much lower fertility. Since the better-educated have on average more career opportunities and are hence more likely to spend time in the labor market, policy interventions that ease the incompatibilities between jobs and children may help narrow the gap between desired and realized family size.

The interventions that have been discussed in the low fertility literature to address the needs of two-breadwinner or female-headed households, regardless of education, seem particularly important in light of our findings (see Brewster and Rindfuss 2000, Kohler et al. 2002, Hank and Kreyenfeld 2003, Rindfuss et al. 2003, DiPrete et al. 2003, Kreyenfeld 2004, European Commission 2005, among others). Policies that facilitate the reentry into the labor market after childbearing, allow for more flexible work schedules, and that provide access to high quality—yet affordable—childcare appear most likely to allow more skilled and career-oriented individuals to have the family of two or more children that many of them still desire. 


\section{References}

Becker, G. S. (1960), "An economic analysis of fertility.” In: Universities National Bureau Committee for Economic Research (ed.), Demographic and Economic Change in Developed Countries, Princeton, New Jersey: Princeton University Press, 209-231.

Bender, D., Bien, W., and H. Bayer (1996), "Wandel und Entwicklung familialer Lebensformen: Datenstruktur des DJI-Familiensurvey. München: unpublished manuscript.

Blake, J. (1966), "Ideal Family Size Among White Americans: A Quarter of a Century's Evidence," Demography, 11(1), 25-44.

Bongaarts, J. (1990), "The Measurement of Wanted Fertility", Population and Development Review, 16(3), 487-506.

Bongaarts, J. (2001), 'Fertility and reproductive preferences in post-transitional societies," Population Council, Policy Research Division Working Paper, No. 114.

Bumpass, L.L., and C.F. Westoff (1970), The Later Years of Childbearing, Princeton: Princeton University Press.

Brewster, K.L., and R.R. Rindfuss (2000), "Fertility and Women's Employment in Industrialized Nations," Annual Review of Sociology, 26, 271-296.

Bytheway, W.R. (1981), "The Variation with Age of Age Differences in Marriage," Journal of Marriage and the Family, 43(4), 923-927.

Chesnais, J.-C. (1996), "Fertility, family and social policy," Population and Development Review, 22(4), 729-739.

Chesnais, J.-C. (2000), "Determinants of below replacement fertility," Population Bulletin of the United Nations, Special Issue 1999, 40/41, Below replacement fertility, 126-136.

Coombs, L.C. (1979), "Reproductive goals and achieved fertility: a fifteen-year perspective”, Demography, 16, 523-534.

DiPrete, T.A., Morgan, S.P., Engelhardt, H., and H. Pacalova (2003), ”Do Cross-National Differences in the Costs of Children Influence Fertility Behavior?", Population Research and Policy Review, $22,439-477$.

DJI Familiensurvey (1988), "Wandel und Entwicklung familialer Lebensformen," Welle 1, Deutsches Jugendinstitut (DJI), München.

DJI Familiensurvey (1994/95), "Wandel und Entwicklung familialer Lebensformen," Welle 2, Deutsches Jugendinstitut (DJI), München.

DJI Familiensurvey (2000), ”Wandel und Entwicklung familialer Lebensformen," Welle 3, Deutsches Jugendinstitut (DJI), München. 
Dorbritz, J. (2003), "Polarisierung versus Vielfalt: Lebensformen und Kinderlosigkeit in Deutschland—eine Auswertung des Mikrozensus," Zeitschrift für Bevölkerungswissenschaft, 28, 403-421.

Elder, G.H. (1985), "Perspectives on the life course." In: G. H. Elder (ed.), Life course dynamics: Trajectories and Transitions, 1968-1980, Ithaca, NY: Cornell University Press, 23-49.

Engelhardt, H. (2004), "Fertility intentions and Preferences: Effects of Structural and Financial Incentives and Constraints in Austria," VID Working Papers 02/2004, Vienna Institute of Demography.

European Commission (2005), "Confronting demographic change: a new solidarity between the generations," Communication from the Commission, Green Paper 2005-94.

EUROSTAT (2001), "Europäische Sozialstatistik Bevölkerung”, Luxembourg: European Communities.

Frejka, T., and G. Calot (2001), "Cohort reproductive patterns in low-fertility countries," Population and Development Review, 27(1), 103-132.

Freedman, R., Freedman, D.S., and A.D. Thornton (1980), "Changes in fertility expectations and preferences between 1962 and 1977: their relation to final parity," Demography, 17(1), 1-11.

Goldstein, J., Lutz, W., and M.R. Testa (2003), "The Emergence of Sub-Replacement Family Size Ideals in Europe," Population Research and Policy Review, Special Issue on Very Low Fertility, $22,479-496$.

Hank, K., and M. Kreyenfeld (2003), "A Multilevel Analysis of Child Care and Women's Fertility Decisions in Western Germany," Journal of Marriage and Family, 65(3), 584-596.

Hausman, J., and D. McFadden (1984), "Specification tests in econometrics," Econometrica, 52, 12191240.

Heiland, F., and A. Prskawetz (2004), "Female Life Cycle Fertility, Demand for Higher Education and Desired Family Size in Post-Transitional Societies: Theory and Evidence from West Germany," Paper presented at the Economic Demography Workshop, Annual Meeting of the Population Association of America, Boston.

Hendershot, G.E., and P.J. Placek (1981), "Predicting Fertility, Demographic Studies of Birth Expectations," Lexington: Lexington Books.

Hirsch, M.B., Seltzer, J.R., and M. Zelnik (1981), ”Desired Family Size of Young American Women, 1971 and 1976." In: Hendershot, G. E. and P. J. Placek (eds.), Predicting Fertility, Lexington, MA: Lexington Books.

Hogan, D.P. (1978), "The variable order of events in the life course," American Sociological Review, 43, 573-586. 
Huinink, J. (2001), 'The Macro-Micro-Link in Demography - Explanations of Demographic Change," Paper presented at the EuroConference "The second demographic transition in Europe", 23-28 June 2001 in Bad Herrenalb, Germany.

Joyce, T., Kaestner, R., and S. Korenman (2002), "Retrospective Assessments of Pregnancy Intentions," Demography, 39(1), 199-213.

Kohler, H.-P., Billari, F.C. and J.A. Ortega (2002), "The emergence of lowest-low fertility in Europe during the 1990s ", Population and Development Review 28(4), 641-680.

Kohler, H.-P. (2001), ”Fertility and Social Interactions: An Economic Perspective," Oxford: Oxford University Press.

Kreyenfeld, M. (2001), 'Employment and Fertility - East Germany in the 1990s," unpublished Ph.D. Thesis, Rostock University.

Kreyenfeld, M. (2002), "Time Squeeze, Partner Effect or Self-Selection? An Investigation into the Positive Effect of Womens Education on Second Birth Risks in West Germany," Demographic Research, 7-2.

Kreyenfeld, M. (2004), "Fertility Decisions in the FRG and GDR: An Analysis with Data from the German Fertility and Family Survey," Demographic Research, Special Collection: Contemporary Research on European Fertility: Perspectives and Developments, S 3-11.

Löhr, C. (1991), "Kinderwunsch und Kinderzahl.” In: Bertram, H. (ed.), Die Familie in Westdeutschland, Stabilität und Wandel familialer Lebensformen, Deutsches Jugendinstitut, Familien-Survey, Vol. 1, Opladen: Leske + Budrich, 461-496.

Lee, R.D. (1980), "Aiming at a Moving Target: Period Fertility and Changing Reproductive Goals," Population Studies, 34, 205-226.

Lesthaeghe, R., and J. Surkyn (1988), "Cultural dynamics and economic theories of fertility change," Population and Development Review, 14(1), 1-45.

Livi Bacci, M. (2001), "Comment: Desired Family size and the future course of fertility," Population and Development Review, Supplement, 27, "Global fertility transition", 282-289.

Lutz, W. (1996), "Future reproductive behavior in industrialized countries." In: Lutz, W. (ed.), The Future Population of the World: What Can We Assume Today?, London: Earthscan Publications.

McCallum, B.T. (1972), "Relative asymptotic bias from errors of omission and measurement," Econometrica, 40(4), 757-758.

McFadden, D. (1974), "Conditional logit analysis of qualitative choice behavior." In: P. Zarembka (ed.), "Frontiers in Econometrics," New York: Academic Press, 105-142.

Menniti, A. (2001), "Fertility intentions and subsequent behavior: first results of a panel study," Paper Presented to the EAPS, European Population Conference, Helsinki, June 7-9. 
Miller, W.B., and D.J. Pasta (1995), "How does childbearing affect fertility motivations and desires?" Social Biology, 42(3-4), 185-198.

Mirowsky, J. (1995), "Age and the Sense of Control," Social Psychology Quarterly, 58(1), 31-43.

Modell, J., Furstenberg, F.F. (Jr.), and T. Hershberg (1976), "Social change and transitions to adulthood in historical perspective," Journal of Family History, 1, 7-32.

Monnnier, A. (1987), "Projects de fécondité et fécondité effective. Une enquête longitudinal: 1974, 1976, 1979," Population, 6, 819-842.

Morgan, P.S. (1981), "Intention and uncertainty at later stages of childbearing: the United States 1965 to 1970," Demography, 18(3), 267-285.

Morgan, P.S. (1982), "Parity-specific fertility intentions and uncertainty: the United States, 1970 to 1976," Demography, 19(3), 215-334.

Morgan, P.S. (1985), "Individual and Couple Intentions for More Children: A Research Note," Demography, 22(1), 125-132.

Nambodiri, K. (1983), "Sequential fertility decision making and the life course." In: R.A. Bulatao and R. Lee (eds.), Determinants of Fertility in Developing Countries, Vol. 2, New York: Academic Press.

Noack, T., and L. Østby (2002), "Free to choose - but unable to stick to it? Norwegian fertility expectations and subsequent behaviour in the following 20 years." In: M. Macura and G. Beets (eds.), Dynamics of Fertility and Partnership in Europe: Insights and Lessons from Comparative Research, Vol. 1, New York and Geneva, United Nations, 103-116.

Pearlin, L.I., and C. Schooler (1978), "The Structure of Coping," Journal of Health and Social Behavior, 19(1), 2-21.

Philipov, D., Spéder, Z., and F.C. Billari (2004), "Fertility intentions in a time of massive societal transformation: theory and evidence from Bulgaria and Hungary," Paper presented at the 2004 Annual Meeting of the Population Association in Boston.

Pritchett, L.H. (1994), "Desired fertility and the impact of population policies," Population and Development Review, 20(1), 1-55.

Quesnel-Vallée, A., and S.P. Morgan (2003), "Missing the Target? Correspondence of fertility intentions and behavior in the U.S.," Population Research and Policy Review, Special Issue on Very Low Fertility, 22(5-6): 497-525.

Rindfuss, R.R., Guzzo, K.B., and S.P. Morgan (2003), "The changing institutional context of low fertility", Population Research and Policy Review, 22, 411-438.

Ryder, N.B. (1973), "A Critique of the National Fertility Study," Demography, 10(4), 495-506. 
Ryder, N.B. (1980), "Components of temporal Variations in American Fertility." In: Hiorns, R. W. (ed.), Demographic Patterns in Developed Societies, London: Taylor \& Francis.

Ryder, N.B. (1981), "Changes in parity orientation from 1970 to 1975." In: Hendershot, G.E. and P.J. Placek (eds.), Predicting Fertility, Lexington, MA: Lexington Books.

Schoen, R., Astone, N.M., Kim, J.Y., Nathanson, C.A., and J.M. Fields (1999), ”Do fertility intentions affect fertility behavior?" Journal of Marriage and the Family, 61(3), 790-799.

Symeonidou, H. (2000), "Expected and Actual Family Size in Greece," European Journal of Population, 16, 335-352.

Statistisches Bundesamt, "Statistisches Jahrbuch der Bundesrepublik Deutschland," Stuttgart: Kohlhammer, various years.

Theil, H. (1969), "A multinomial extension of the linear of the linear logit model," International Economics Review, 10, 251-259.

Theil, H. (1970), "On the estimation of relationships involving qualitative data," American Journal of Sociology, 76, 103-154.

Thomson, E., McDonald, E., and L.L. Bumpass (1990), "Fertility Desires and Fertility: Hers, His, and Theirs," Demography, 27(4), 579-588.

Thomson, E. (1997), "Couple Childbearing Desires, Intentions, and Births," Demography, 34(3), 343354.

Thornton, A.D., Freedman, R., and D.S. Freedman (1984), "Further Reflections on Changes in Fertility Expectations and Preferences," Research Notes, Commentary and Debate, Demography, 21(3), 423-429.

Van de Kaa, D.J. (2001), "Postmodern fertility preferences: from changing value orientation to new behavior," Population and Development Review, Supplement, 27, "Global fertility transition", 290-331.

Van Hoorn, W., and N. Keilman (1997), "Births expectations and their use in fertility forecasting," Eurostat Working Paper E4/1997-4.

Van Peer, C. (2002), "Desired and Realized Fertility in selected FFS-countries." In: M. Macura and G. Beets (eds.), Dynamics of Fertility and Partnership in Europe: Insights and Lessons from Comparative Research, Vol. 1, New York and Geneva, United Nations, 117-142.

Walker, J.R. (2003), "Pregnancy and Fertility Expectations: Estimates of Bounded Rationality and Unintended Births," Unpublished Working Paper, University of Wisconsin-Madison.

Westoff, C.F., and N.B. Ryder (1977), "The predictive validity of reproductive intentions," Demography, 14, 431-453. 
Westoff, C.F. (1981), "The validity of birth intentions: evidence from U.S. longitudinal studies." In: Hendershot, G. E., and P. J. Placek (eds.), Predicting Fertility, Lexington, MA: Lexington Books.

Willis, R. (1973), "A New Approach to the Economic Theory of Fertility Behavior," Journal of Political Economy, 81, 514-564. 


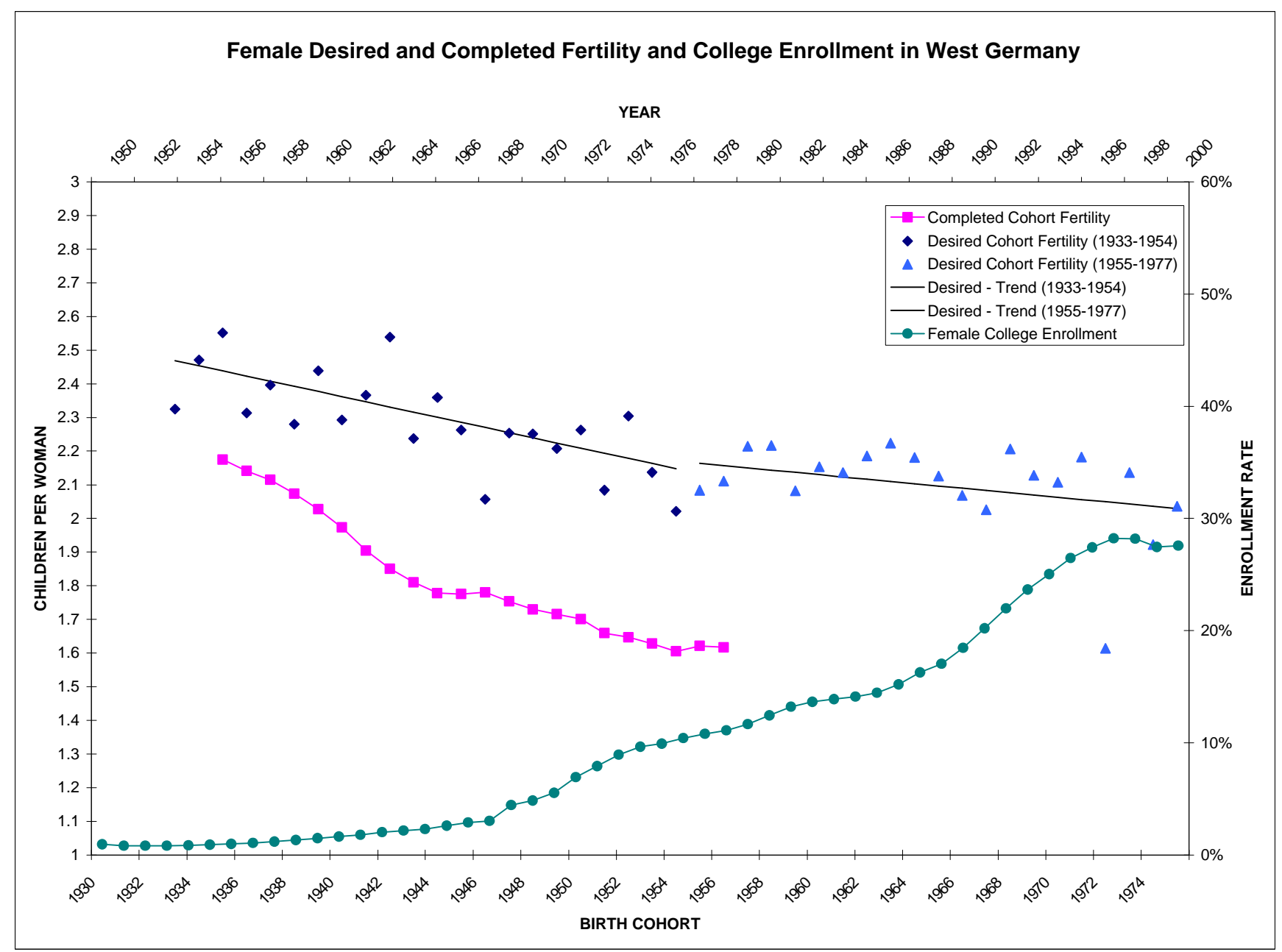

Figure 1: Desired and Actual Number of Children of Selected West German Female Cohorts, and Female College Enrollment Rates. (Sources: DJI Familiensurvey 1988 and 1994/95; Statistisches Jahrbuch der Bundesrepublik Deutschland various years) 

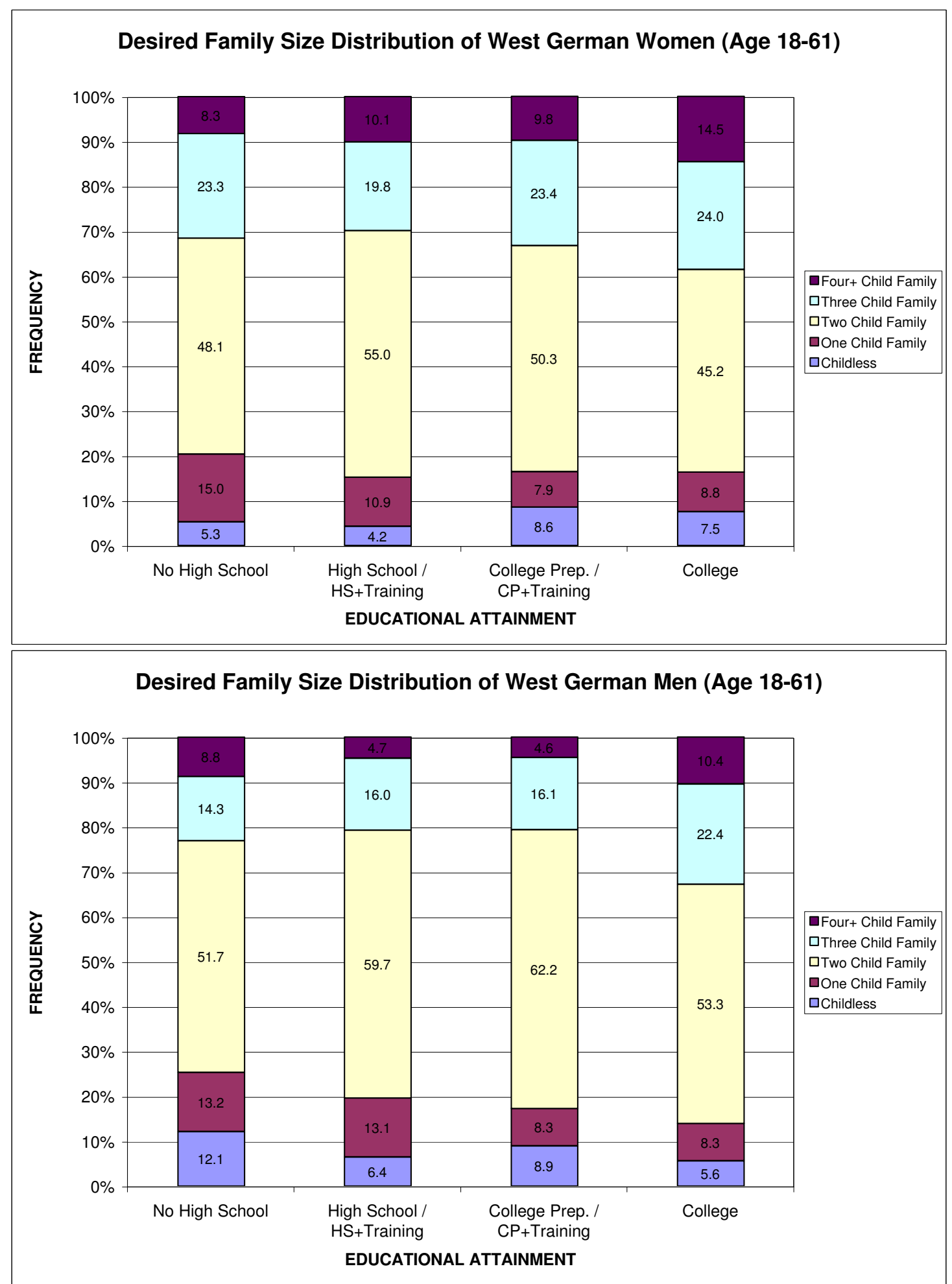

Figure 2: Distribution of Desired Family Size of West German Men and Women by Educational Attainment (Source: DJI Familiensurvey 1988 and 1994/95) 
Table 1: Means of Variables (West Germany)

\begin{tabular}{|c|c|c|c|c|c|}
\hline \multirow[b]{2}{*}{ Variable Name } & \multirow[b]{2}{*}{ Definition } & \multicolumn{4}{|c|}{ Sample Mean ${ }^{a}$} \\
\hline & & Women & Men & $\begin{array}{c}\text { Women } \\
\text { 18-35 }\end{array}$ & $\begin{array}{c}\text { Women } \\
1994\end{array}$ \\
\hline \multicolumn{6}{|l|}{ Children } \\
\hline Desired & total desired number of children & 2.21 & 2.03 & 2.12 & 2.21 \\
\hline None Desired & desired no children & 0.05 & 0.07 & 0.06 & 0.05 \\
\hline One Desired & desired one child & 0.10 & 0.12 & 0.10 & 0.10 \\
\hline Two Desired & desired two children & 0.53 & 0.59 & 0.57 & 0.54 \\
\hline Three Desired & desired three children & 0.21 & 0.17 & 0.19 & 0.20 \\
\hline Four+ Desired & desired four or more children & 0.10 & 0.06 & 0.08 & 0.11 \\
\hline Actual & total actual number of children & 1.43 & 1.09 & 0.90 & 1.44 \\
\hline No Child & has/had no child at time of interview & 0.28 & 0.43 & 0.48 & 0.28 \\
\hline One Child & has/had one child at time of interview & 0.23 & 0.19 & 0.23 & 0.22 \\
\hline Two Children & has/had two children at time of interview & 0.33 & 0.26 & 0.23 & 0.34 \\
\hline Three Children & has/had three children at time of interview & 0.11 & 0.09 & 0.05 & 0.11 \\
\hline Four+ Children & has/had four+ children at time of interview & 0.05 & 0.03 & 0.01 & 0.05 \\
\hline \multicolumn{6}{|l|}{ Characteristics } \\
\hline Catholic & respondent's religious affiliation is Catholic & 0.42 & 0.42 & 0.44 & 0.42 \\
\hline Both Parents & grew up with both parents & 0.88 & 0.88 & 0.91 & 0.88 \\
\hline Traditional & 'women should work less in labor market than men' & 0.10 & 0.14 & 0.07 & 0.08 \\
\hline Ingle Type ${ }^{b}$ PPM & strong post-materialistic views on Inglehart Scale & 0.30 & 0.35 & 0.35 & 0.29 \\
\hline Ingle Type PMP & intermediate post-materialistic views on Inglehart Scale & 0.16 & 0.17 & 0.17 & 0.17 \\
\hline Ingle Type PMM & weak post-materialistic views on Inglehart Scale & 0.10 & 0.09 & 0.10 & 0.11 \\
\hline Ingle Type MPP & weak materialistic views on Inglehart Scale & 0.20 & 0.20 & 0.19 & 0.19 \\
\hline Ingle Type MPM & intermediate materialistic views on Inglehart Scale & 0.12 & 0.10 & 0.10 & 0.12 \\
\hline Ingle Type MMP & strong materialistic views on Inglehart Scale & 0.11 & 0.08 & 0.08 & 0.10 \\
\hline Ingle Missing & Inglehart missing & 0.01 & 0.01 & 0.01 & 0.01 \\
\hline Health Status & self-reported health scale $(1-5 ; 1=$ very good, $5=$ poor $)$ & 2.18 & 2.09 & 1.95 & 2.18 \\
\hline \multicolumn{6}{|l|}{ Education $^{c}$} \\
\hline No HS & has no high school diploma & 0.02 & 0.01 & 0.01 & 0.01 \\
\hline HS & has only high school diploma & 0.20 & 0.09 & 0.17 & 0.17 \\
\hline HS+Training & received high school diploma and training & 0.57 & 0.60 & 0.54 & 0.58 \\
\hline $\mathrm{CP}$ & received only college preparatory diploma & 0.05 & 0.07 & 0.09 & 0.05 \\
\hline CP+Training & received college preparatory diploma and training & 0.07 & 0.08 & 0.11 & 0.09 \\
\hline College & graduated from university or technical college & 0.09 & 0.15 & 0.08 & 0.10 \\
\hline \multicolumn{6}{|l|}{ Labor Force Status } \\
\hline Employed & in labor force and employed & 0.53 & 0.80 & 0.53 & 0.59 \\
\hline Unemployed & in labor force and unemployed & 0.03 & 0.03 & 0.03 & 0.03 \\
\hline In Household & not in labor force and at home & 0.32 & 0.00 & 0.26 & 0.26 \\
\hline In School & not in labor force and in school & 0.07 & 0.11 & 0.14 & 0.08 \\
\hline Other Status & not in labor force and other activity (incl. retired) & 0.04 & 0.05 & 0.04 & 0.04 \\
\hline \multicolumn{6}{|l|}{ Income ${ }^{d}$} \\
\hline Income $0-2$ & household monthly real disposable income is $0-2000$ & 0.18 & 0.14 & 0.24 & 0.16 \\
\hline Income $2-4$ & household monthly real disposable income is $2000-4000$ & 0.61 & 0.62 & 0.61 & 0.50 \\
\hline Income 4+ & household monthly real disposable income is $4000+$ & 0.21 & 0.24 & 0.15 & 0.34 \\
\hline Inc Missing & household disposable income info missing & 0.11 & 0.10 & 0.12 & 0.12 \\
\hline Survey 88 & respondent is in 1988 wave of the survey & 0.59 & 0.59 & 0.60 & 0.00 \\
\hline Panel & respondent is in both waves of the survey & 0.61 & 0.58 & 0.49 & 0.74 \\
\hline Sample Size & & 8,616 & 6,913 & 4,150 & 3,558 \\
\hline
\end{tabular}

Notes: ${ }^{a}$ Mean is computed for individuals with complete information only. Information relates to the time of the interview. ${ }^{b}$ Ranking of two post-materialistic (P) versus two materialistic (M) objectives: first letter expresses highest priority and last letter ęxpresses lowest. ${ }^{c}$ Highest Education/Training completed. ${ }^{d}$ Categorization based on 1988 Deutschmarks. 1988 and 1994 are made comparable using the CPI (Preisindex für die Lebenshaltung_Alle Privaten Haushalte') for West Germany. 
Table 1 (continued): Means of Variables (West Germany)

\begin{tabular}{|c|c|c|c|c|c|}
\hline \multirow[b]{2}{*}{ Variable Name } & \multirow[b]{2}{*}{ Definition } & \multicolumn{4}{|c|}{ Mean $^{a}$} \\
\hline & & Women & Men & $\begin{array}{c}\text { Women } \\
18-35\end{array}$ & $\begin{array}{c}\text { Women } \\
1994\end{array}$ \\
\hline \multicolumn{6}{|l|}{ Age } \\
\hline Age at Int. & age at interview in years & 37.0 & 36.6 & 27.4 & 37.6 \\
\hline Age20 & age group $20(18<$ age $\leq 20)$ & 0.05 & 0.06 & 0.10 & 0.05 \\
\hline Age25 & age group $25(21<$ age $\leq 25)$ & 0.12 & 0.13 & 0.25 & 0.10 \\
\hline Age30 & age group $30(25<$ age $\leq 30)$ & 0.17 & 0.19 & 0.36 & 0.20 \\
\hline Age35 & age group $35(30<$ age $\leq 35)$ & 0.14 & 0.13 & 0.29 & 0.12 \\
\hline Age 40 & age group $40(35<$ age $\leq 40)$ & 0.15 & 0.12 & & 0.14 \\
\hline Age45 & age group $45(40<$ age $<45)$ & 0.12 & 0.11 & & 0.12 \\
\hline Age50 & age group $50(45<$ age $\leq 50)$ & 0.11 & 0.11 & & 0.08 \\
\hline Age60 & age group $60(50<$ age $\leq 60)$ & 0.15 & 0.15 & & 0.19 \\
\hline Rural & residential category $\left(0-9 ; 0={ }^{\prime}>0.5\right.$ mill.', $\left.9==^{\prime}<2,000 .^{\prime}\right)$ & 3.37 & 3.47 & 3.33 & 3.49 \\
\hline \multicolumn{6}{|l|}{ Partnership } \\
\hline Married & married at time of interview & 0.69 & 0.59 & 0.54 & 0.68 \\
\hline Marriedt & married and living together & 0.67 & 0.58 & 0.52 & 0.66 \\
\hline Marrieds & married and separated & 0.02 & 0.01 & 0.02 & 0.02 \\
\hline Divorced & divorced at time of interview & 0.06 & 0.05 & 0.04 & 0.06 \\
\hline Divorcep & divorced and living with a partner & 0.03 & 0.03 & 0.02 & 0.03 \\
\hline Divorcenp & divorced and living without a partner & 0.03 & 0.02 & 0.02 & 0.03 \\
\hline Widowed & widowed at time of interview & 0.03 & 0.01 & 0.00 & 0.03 \\
\hline Single & single at time of interview & 0.22 & 0.35 & 0.41 & 0.23 \\
\hline Singlep & single and living with a partner & 0.13 & 0.17 & 0.26 & 0.14 \\
\hline Singlenp & single and living without a partner & 0.09 & 0.18 & 0.16 & 0.09 \\
\hline \multicolumn{6}{|c|}{ Parents' Education ${ }^{b}$} \\
\hline No HSF & father has no high school diploma & 0.08 & 0.07 & 0.06 & 0.07 \\
\hline HSF & father has only high school diploma & 0.13 & 0.12 & 0.11 & 0.12 \\
\hline HSF+Training & father received high school diploma and training & 0.66 & 0.68 & 0.68 & 0.67 \\
\hline College PrepF & father received college preparatory diploma & 0.02 & 0.03 & 0.02 & 0.03 \\
\hline CollegeF & father graduated from college & 0.11 & 0.10 & 0.12 & 0.11 \\
\hline EDUF Missing & father's educational attainment info missing & 0.10 & 0.08 & 0.10 & 0.11 \\
\hline No HSM & mother has no high school diploma & 0.08 & 0.07 & 0.07 & 0.07 \\
\hline HSM & mother has only high school diploma & 0.44 & 0.45 & 0.35 & 0.41 \\
\hline HSM+Training & mother received high school diploma and training & 0.43 & 0.41 & 0.51 & 0.45 \\
\hline College PrepM & mother received college preparatory diploma & 0.05 & 0.04 & 0.05 & 0.08 \\
\hline CollegeM & mother graduated from college & 0.02 & 0.03 & 0.03 & 0.03 \\
\hline EDUM Missing & mother's educational attainment info missing & 0.11 & 0.10 & 0.11 & 0.11 \\
\hline \multicolumn{6}{|l|}{ Siblings } \\
\hline Num. Siblings & number of siblings & 1.85 & 1.77 & 1.75 & 1.93 \\
\hline No Siblings & has/had no siblings & 0.13 & 0.15 & 0.15 & 0.19 \\
\hline One Sibling & has/had one sibling & 0.31 & 0.32 & 0.31 & 0.27 \\
\hline Two Siblings & has/had two siblings & 0.24 & 0.23 & 0.25 & 0.24 \\
\hline Three+ Siblings & has/had three siblings & 0.32 & 0.30 & 0.29 & 0.30 \\
\hline Sib. Missing & sibling info missing & 0.09 & 0.10 & 0.18 & 0.19 \\
\hline Sample Size & & 8,616 & 6,913 & 4,150 & 3,558 \\
\hline
\end{tabular}

Notes: ${ }^{a}$ Mean is computed for individuals with complete information only. Information relates to the time of the interview. ${ }^{b}$ Highest Education and Training completed. 
Table 2: Desired vs. Realized ${ }^{a}$ Number of Children in West Germany by Education, Gender and Age

\begin{tabular}{|c|c|c|c|c|c|c|}
\hline Group & Average & No HS & HS & HS+Training & CP/CP+Training & College \\
\hline \multicolumn{7}{|c|}{ Women: $36-45$ Year Old } \\
\hline Desired & 2.20 & 1.96 & 2.28 & 2.16 & 2.25 & 2.27 \\
\hline Realized & 1.78 & 1.71 & 2.02 & 1.76 & 1.66 & 1.66 \\
\hline Gap & 0.42 & 0.25 & 0.26 & 0.4 & 0.59 & 0.61 \\
\hline Mean Absolute Difference & 0.67 & 0.61 & 0.69 & 0.64 & 0.75 & 0.76 \\
\hline$\%$ Desired $>$ Realized & 37.8 & 28.6 & 34.1 & 36.5 & 44.6 & 46.7 \\
\hline$\%$ Desired $<$ Realized & 9.2 & 7.1 & 14.6 & 8.8 & 5.4 & 5.9 \\
\hline$(\mathrm{N})$ & $(2,261)$ & $(28)$ & $(378)$ & $(1,437)$ & $(112)$ & $(306)$ \\
\hline \multicolumn{7}{|c|}{ Women: 46-61 Year Old } \\
\hline Desired & 2.38 & 2.15 & 2.37 & 2.37 & 2.52 & 2.55 \\
\hline Realized & 2.07 & 2.32 & 2.32 & 1.97 & 1.87 & 1.71 \\
\hline Gap & 0.31 & -0.17 & 0.05 & 0.4 & 0.65 & 0.84 \\
\hline Mean Absolute Difference & 0.71 & 0.94 & 0.61 & 0.71 & 0.80 & 0.96 \\
\hline$\%$ Desired $>$ Realized & 33.8 & 27.7 & 24.4 & 36.3 & 44.7 & 51.1 \\
\hline$\%$ Desired $<$ Realized & 14.0 & 29.8 & 20.2 & 11.6 & 6.4 & 4.9 \\
\hline$(\mathrm{N})$ & $(2,205)$ & $(47)$ & $(672)$ & $(1,251)$ & (94) & $(141)$ \\
\hline \multicolumn{7}{|c|}{ Men: 36-45 Year Old } \\
\hline Desired & 2.02 & 1.95 & 2.08 & 2.00 & 1.91 & 2.13 \\
\hline Realized & 1.58 & 1.74 & 1.44 & 1.66 & 1.25 & 1.52 \\
\hline Gap & 0.44 & 0.21 & 0.62 & 0.34 & 0.66 & 0.61 \\
\hline Mean Absolute Difference & 0.66 & 0.63 & 0.81 & 0.60 & 0.85 & 0.73 \\
\hline$\%$ Desired $>$ Realized & 37.1 & 26.3 & 50.0 & 33.6 & 44.5 & 42.2 \\
\hline$\%$ Desired $<$ Realized & 8.7 & 21.1 & 6.0 & 10.0 & 7.0 & 5.3 \\
\hline$(\mathrm{N})$ & $(1,580)$ & (19) & (84) & $(1,010)$ & $(128)$ & (339) \\
\hline \multicolumn{7}{|c|}{ Men: 46-61 Year Old } \\
\hline Desired & 2.15 & 2.16 & 2.16 & 2.08 & 2.25 & 2.40 \\
\hline Realized & 1.85 & 1.79 & 1.79 & 1.85 & 1.87 & 1.87 \\
\hline Gap & 0.30 & 0.37 & 0.37 & 0.23 & 0.38 & 0.53 \\
\hline Mean Absolute Difference & 0.64 & 0.79 & 0.63 & 0.62 & 0.67 & 0.73 \\
\hline$\%$ Desired $>$ Realized & 31.1 & 42.1 & 30.5 & 29.4 & 32.1 & 37.0 \\
\hline$\%$ Desired $<$ Realized & 13.1 & 21.1 & 10.6 & 14.7 & 11.9 & 7.7 \\
\hline$(\mathrm{N})$ & $(1,843)$ & (19) & $(151)$ & $(1,265)$ & (84) & $(324)$ \\
\hline
\end{tabular}

Notes: ${ }^{a}$ Due to data limitations 'Desired Number of Children' is measured on a scale from zero to 'four or more'. For consistency the scale for 'Actual Number of Children' is chosen accordingly. 
Table 3: Estimated Effect of Education on Desired Fertility in West Germany: Women by Age

\begin{tabular}{|c|c|c|c|c|c|c|}
\hline \multirow[b]{2}{*}{ Variable Name } & \multicolumn{3}{|c|}{ Not Controlling for Children } & \multicolumn{3}{|c|}{ Controlling for Children } \\
\hline & 0 & 1 & $3,4+$ & 0 & 1 & $3,4+$ \\
\hline & \multicolumn{6}{|c|}{ 18-35 Year Old $(N=4,150)$} \\
\hline \multirow[t]{2}{*}{ No HS } & 0.200 & 0.192 & 0.243 & 0.621 & 0.135 & 0.122 \\
\hline & $(0.822)$ & $(0.515)$ & $(0.330)$ & $(0.800)$ & $(0.523)$ & $(0.336)$ \\
\hline \multirow[t]{2}{*}{ HS (no training) } & 0.058 & 0.205 & 0.060 & 0.174 & 0.202 & -0.126 \\
\hline & $(0.268)$ & $(0.162)$ & $(0.121)$ & $(0.291)$ & $(0.170)$ & $(0.130)$ \\
\hline \multicolumn{7}{|c|}{ HS+Training (Ref.) } \\
\hline \multirow[t]{2}{*}{$\mathbf{C P}$} & -0.079 & -0.144 & $\mathbf{0 . 3 7 3}{ }^{* *}$ & -0.153 & -0.130 & $0.309^{*}$ \\
\hline & $(0.285)$ & $(0.279)$ & $(0.168)$ & $(0.291)$ & $(0.287)$ & $(0.173)$ \\
\hline \multirow[t]{2}{*}{ CP+Training } & 0.003 & $-0.358^{*}$ & $\mathbf{0 . 3 8 4} 4^{* * *}$ & -0.162 & $-0.435^{* *}$ & $0.468^{* * *}$ \\
\hline & $(0.235)$ & $(0.216)$ & $(0.139)$ & $(0.244)$ & $(0.215)$ & $(0.141)$ \\
\hline \multirow[t]{2}{*}{ College } & -0.249 & -0.218 & $\mathbf{0 . 4 4 6} 6^{* * *}$ & -0.274 & -0.344 & $\mathbf{0 . 5 9 2} 2^{* * *}$ \\
\hline & $(0.276)$ & $(0.235)$ & $(0.150)$ & $(0.283)$ & $(0.240)$ & $(0.155)$ \\
\hline \multirow[t]{2}{*}{$R^{2}$} & & 0.084 & & & 0.158 & \\
\hline & \multicolumn{6}{|c|}{ 36-45 Year Old $(N=2,261)$} \\
\hline \multirow[t]{2}{*}{ No HS } & 0.087 & $1.283^{* *}$ & 0.138 & 0.689 & 0.904 & -0.060 \\
\hline & $(0.987)$ & $(0.576)$ & $(0.503)$ & $(0.993)$ & $(0.622)$ & $(0.480)$ \\
\hline \multirow[t]{2}{*}{ HS (no training) } & -0.235 & -0.138 & 0.093 & -0.108 & -0.221 & -0.065 \\
\hline & $(0.355)$ & $(0.203)$ & $(0.144)$ & $(0.392)$ & $(0.219)$ & $(0.167)$ \\
\hline \multicolumn{7}{|c|}{ HS+Training (Ref.) } \\
\hline \multirow[t]{2}{*}{$\mathbf{C P}$} & 0.194 & 0.631 & 0.364 & -0.364 & 0.528 & -0.175 \\
\hline & $(1.181)$ & $(0.566)$ & $(0.425)$ & $(1.263)$ & $(0.706)$ & $(0.400)$ \\
\hline \multirow[t]{2}{*}{ CP+Training } & 0.239 & -0.639 & 0.067 & 0.521 & -0.721 & 0.185 \\
\hline & $(0.595)$ & $(0.436)$ & $(0.280)$ & $(0.690)$ & $(0.462)$ & $(0.275)$ \\
\hline \multirow[t]{2}{*}{ College } & 0.303 & -0.109 & $0.455^{* * *}$ & 0.340 & -0.019 & $\mathbf{0 . 4 5 6}^{* *}$ \\
\hline & $(0.385)$ & $(0.273)$ & $(0.173)$ & $(0.432)$ & $(0.288)$ & $(0.188)$ \\
\hline$R^{2}$ & & 0.075 & & & 0.230 & \\
\hline
\end{tabular}

\section{6-61 Year Old $(\mathrm{N}=2,205)$}

\begin{tabular}{|c|c|c|c|c|c|c|}
\hline No HS & $\begin{array}{l}\mathbf{1 . 7 3 4}^{* *} \\
(0.702)\end{array}$ & $\begin{array}{c}\mathbf{0 . 6 5 0} \\
(0.494)\end{array}$ & $\begin{array}{c}\mathbf{0 . 0 6 9} \\
(0.369)\end{array}$ & $\begin{array}{c}\mathbf{2 . 8 9 8}^{* * *} \\
(0.698)\end{array}$ & $\begin{array}{c}\mathbf{0 . 4 0 6} \\
(0.592)\end{array}$ & $\begin{array}{c}\mathbf{- 0 . 3 9 9} \\
(0.410)\end{array}$ \\
\hline HS (no training) & $\begin{array}{c}\mathbf{0 . 0 5 0} \\
(0.375)\end{array}$ & $\begin{array}{c}\mathbf{0 . 1 8 0} \\
(0.204)\end{array}$ & $\begin{array}{l}\mathbf{- 0 . 1 8 8} \\
(0.129)\end{array}$ & $\begin{array}{c}\mathbf{0 . 4 8 1} \\
(0.442)\end{array}$ & $\begin{array}{c}\mathbf{0 . 1 4 0} \\
(0.220)\end{array}$ & $\begin{array}{r}\mathbf{- 0 . 4 5 3}^{* *} \\
(0.144)\end{array}$ \\
\hline \multicolumn{7}{|l|}{ HS+Training (Ref.) } \\
\hline CP/CP+Training & $\begin{array}{c}\mathbf{- 0 . 4 2 6} \\
(0.861)\end{array}$ & $\begin{array}{c}\mathbf{0 . 1 6 3} \\
(0.460)\end{array}$ & $\begin{array}{c}\mathbf{0 . 3 5 9} \\
(0.262)\end{array}$ & $\begin{array}{c}\mathbf{- 0 . 6 6 0} \\
(0.899)\end{array}$ & $\begin{array}{c}\mathbf{0 . 0 5 0} \\
(0.448)\end{array}$ & $\begin{array}{c}\mathbf{0 . 4 6 6} \\
(0.303)\end{array}$ \\
\hline College & $\begin{array}{c}\mathbf{0 . 2 9 5} \\
(0.560)\end{array}$ & $\begin{array}{l}-\mathbf{- 0 . 2 8 1} \\
(0.441)\end{array}$ & $\begin{array}{l}\mathbf{0 . 4 7 9}^{* *} \\
(0.227)\end{array}$ & $\begin{array}{c}\mathbf{0 . 0 7 5} \\
(0.582)\end{array}$ & $\begin{array}{l}-\mathbf{0 . 4 0 2} \\
(0.497)\end{array}$ & $\begin{array}{c}\mathbf{0 . 5 3 6}^{* *} \\
(0.247)\end{array}$ \\
\hline$R^{2}$ & & 0.087 & & & 0.241 & \\
\hline
\end{tabular}

Notes: Table reports estimated effects on log-odds ratios. All models also include controls for the 10 states and missing data on post-materialism, income, siblings, and parents' education. Robust standard errors that correct for clustering of individuals who interviewed in both survey rounds are in parentheses. ${ }^{*}$ Statistically significant at the .10 level; ${ }^{* *}$ at the .05 level (two-tailed test); ${ }^{* * *}$ at the .01 level (two-tailed test). 
Table 4: Predicted ${ }^{a}$ Desired Fertility in West Germany: Women by Age and Education

\begin{tabular}{llllllllll}
\hline & \multicolumn{3}{c}{ Not Controlling for Children } & \multicolumn{4}{c}{ Controlling for Children } \\
Variable Name & 0 & 1 & 2 & $3,4+$ & 0 & 1 & 2 & $3,4+$ \\
\hline
\end{tabular}

\section{8-35 Year Old $(\mathrm{N}=4,150)$}

$\begin{array}{lllllllll}\text { Within Sample } & 0.062 & 0.102 & 0.566 & 0.270 & 0.062 & 0.102 & 0.566 & 0.270 \\ \text { No HS } & 0.072 & 0.118 & 0.529 & 0.281 & 0.101 & 0.113 & 0.529 & 0.257 \\ \text { HS } & 0.066 & 0.126 & 0.558 & 0.250 & 0.076 & 0.128 & 0.572 & 0.224 \\ \text { HS+Training } & 0.066 & 0.107 & 0.582 & 0.245 & 0.066 & 0.108 & 0.576 & 0.249 \\ \text { College Prep. } & 0.057 & 0.087 & 0.536 & 0.320 & 0.056 & 0.093 & 0.546 & 0.305 \\ \text { CP+Training } & 0.062 & 0.072 & 0.540 & 0.326 & 0.055 & 0.070 & 0.535 & 0.341 \\ \text { College } & 0.049 & 0.081 & 0.531 & 0.339 & 0.049 & 0.073 & 0.514 & 0.365\end{array}$

\section{6-45 Year Old $(\mathrm{N}=2,261)$}

$\begin{array}{lllllllll}\text { Within Sample } & 0.047 & 0.126 & 0.517 & 0.310 & 0.047 & 0.126 & 0.517 & 0.310 \\ \text { No HS } & 0.036 & 0.325 & 0.388 & 0.250 & 0.062 & 0.232 & 0.450 & 0.257 \\ \text { HS } & 0.038 & 0.116 & 0.529 & 0.317 & 0.044 & 0.113 & 0.547 & 0.296 \\ \text { HS+Training } & 0.047 & 0.132 & 0.530 & 0.292 & 0.046 & 0.131 & 0.524 & 0.300 \\ \text { College Prep. } & 0.045 & 0.194 & 0.425 & 0.335 & 0.034 & 0.195 & 0.512 & 0.259 \\ \text { CP+Training } & 0.060 & 0.073 & 0.547 & 0.320 & 0.064 & 0.070 & 0.523 & 0.343 \\ \text { College } & 0.054 & 0.103 & 0.455 & 0.388 & 0.053 & 0.115 & 0.456 & 0.377\end{array}$

46-61 Year Old $(\mathrm{N}=2,205)$

$\begin{array}{lllllllll}\text { Within Sample } & 0.034 & 0.087 & 0.492 & 0.388 & 0.034 & 0.087 & 0.492 & 0.388 \\ \text { No HS } & 0.118 & 0.124 & 0.407 & 0.351 & 0.176 & 0.103 & 0.432 & 0.289 \\ \text { HS } & 0.035 & 0.101 & 0.517 & 0.347 & 0.045 & 0.100 & 0.532 & 0.323 \\ \text { HS+Training } & 0.032 & 0.081 & 0.493 & 0.394 & 0.030 & 0.082 & 0.482 & 0.406 \\ \text { College Prep./ } & 0.020 & 0.083 & 0.425 & 0.473 & 0.017 & 0.075 & 0.414 & 0.494 \\ \text { CP+Training } & & & & & & & & \\ \text { College } & 0.035 & 0.052 & 0.408 & 0.505 & 0.028 & 0.051 & 0.409 & 0.511\end{array}$

Notes: ${ }^{a}$ The predictions by educational attainment are obtained by assuming that all individuals in the sample have the same educational attainment while using the individual data for all other covariates. 
Table 5: Estimated Effect of Education on Desired Fertility in West Germany: Men by Age

\begin{tabular}{|c|c|c|c|c|c|c|}
\hline \multirow[b]{2}{*}{ Variable Name } & \multicolumn{3}{|c|}{ Not Controlling for Children } & \multicolumn{3}{|c|}{ Controlling for Children } \\
\hline & 0 & 1 & $3,4+$ & 0 & 1 & $3,4+$ \\
\hline & \multicolumn{6}{|c|}{ 18-35 Year Old $(N=3,490)$} \\
\hline \multirow[t]{2}{*}{ No HS } & 0.200 & 0.192 & 0.243 & 0.621 & 0.135 & 0.122 \\
\hline & $(0.822)$ & $(0.515)$ & $(0.330)$ & $(0.800)$ & $(0.523)$ & $(0.336)$ \\
\hline \multirow[t]{2}{*}{ HS (no training) } & 0.058 & 0.205 & 0.060 & 0.174 & 0.202 & -0.126 \\
\hline & $(0.268)$ & $(0.162)$ & $(0.121)$ & $(0.291)$ & $(0.170)$ & $(0.130)$ \\
\hline \multicolumn{7}{|c|}{ HS+Training (Ref.) } \\
\hline \multirow[t]{2}{*}{$\mathbf{C P}$} & -0.079 & -0.144 & $\mathbf{0 . 3 7 3}{ }^{* *}$ & -0.153 & -0.130 & $0.309^{*}$ \\
\hline & $(0.285)$ & $(0.279)$ & $(0.168)$ & $(0.291)$ & $(0.287)$ & $(0.173)$ \\
\hline \multirow[t]{2}{*}{ CP+Training } & 0.003 & $-0.358^{*}$ & $\mathbf{0 . 3 8 4} 4^{* * *}$ & -0.162 & $-0.435^{* *}$ & $0.468^{* * *}$ \\
\hline & $(0.235)$ & $(0.216)$ & $(0.139)$ & $(0.244)$ & $(0.215)$ & $(0.141)$ \\
\hline \multirow[t]{2}{*}{ College } & -0.249 & -0.218 & $0.446^{* * *}$ & -0.274 & -0.344 & $\mathbf{0 . 5 9 2} 2^{* * *}$ \\
\hline & $(0.276)$ & $(0.235)$ & $(0.150)$ & $(0.283)$ & $(0.240)$ & $(0.155)$ \\
\hline \multirow[t]{2}{*}{$R^{2}$} & & 0.081 & & & 0.124 & \\
\hline & \multicolumn{6}{|c|}{ 36-45 Year Old $(N=1,580)$} \\
\hline \multirow[t]{2}{*}{ No HS } & 0.087 & $1.283^{* *}$ & 0.138 & 0.689 & 0.904 & -0.060 \\
\hline & $(0.987)$ & $(0.576)$ & $(0.503)$ & $(0.993)$ & $(0.622)$ & $(0.480)$ \\
\hline \multirow[t]{2}{*}{ HS (no training) } & -0.235 & -0.138 & 0.093 & -0.108 & -0.221 & -0.065 \\
\hline & $(0.355)$ & $(0.203)$ & $(0.144)$ & $(0.392)$ & $(0.219)$ & $(0.167)$ \\
\hline \multicolumn{7}{|l|}{ HS+Training (Ref.) } \\
\hline \multirow[t]{2}{*}{$\mathbf{C P}$} & 0.194 & 0.631 & 0.364 & -0.364 & 0.528 & -0.175 \\
\hline & $(1.181)$ & $(0.566)$ & $(0.425)$ & $(1.263)$ & $(0.706)$ & $(0.400)$ \\
\hline \multirow[t]{2}{*}{ CP+Training } & 0.239 & -0.639 & 0.067 & 0.521 & -0.721 & 0.185 \\
\hline & $(0.595)$ & $(0.436)$ & $(0.280)$ & $(0.690)$ & $(0.462)$ & $(0.275)$ \\
\hline \multirow[t]{2}{*}{ College } & 0.303 & -0.109 & $\mathbf{0 . 4 5 5 ^ { * * * }}$ & 0.340 & -0.019 & $0.456^{* *}$ \\
\hline & $(0.385)$ & $(0.273)$ & $(0.173)$ & $(0.432)$ & $(0.288)$ & $(0.188)$ \\
\hline \multirow[t]{2}{*}{$R^{2}$} & & 0.110 & & & 0.270 & \\
\hline & \multicolumn{6}{|c|}{ 46-61 Year Old $(N=1,843)$} \\
\hline \multirow[t]{2}{*}{ No HS } & 0.303 & -1.004 & -0.641 & 0.034 & -1.258 & -0.646 \\
\hline & $(1.341)$ & $(1.089)$ & $(0.633)$ & $(1.766)$ & $(1.161)$ & $(0.753)$ \\
\hline \multirow[t]{2}{*}{ HS (no training) } & $0.649^{*}$ & $0.588^{*}$ & $0.524^{* *}$ & $0.634^{*}$ & 0.358 & $0.551^{* *}$ \\
\hline & $(0.394)$ & $(0.307)$ & $(0.238)$ & $(0.368)$ & $(0.355)$ & $(0.274)$ \\
\hline \multicolumn{7}{|l|}{ HS+Training (Ref.) } \\
\hline \multirow[t]{2}{*}{ CP/CP+Training } & 0.000 & $-\mathbf{0 . 8 3 5}{ }^{*}$ & 0.263 & -0.492 & -0.763 & 0.297 \\
\hline & $(0.520)$ & $(0.476)$ & $(0.276)$ & $(0.706)$ & $(0.531)$ & $(0.288)$ \\
\hline \multirow[t]{2}{*}{ College } & -0.247 & $-0.685^{* *}$ & $\mathbf{0 . 7 5 0} 0^{* * *}$ & -0.435 & $-0.614^{*}$ & $\mathbf{0 . 9 2 3}^{* * *}$ \\
\hline & $(0.386)$ & $(0.288)$ & $(0.182)$ & $(0.378)$ & $(0.334)$ & (0.209) \\
\hline$R^{2}$ & & 0.095 & & & 0.276 & \\
\hline
\end{tabular}

Notes: Table reports estimated effects on log-odds ratios. All models also include binary controls for the 10 states and missing data on post-materialism, income, siblings, and parents' education. Robust standard errors that correct for clustering of individyals who interviewed in both survey rounds are in parentheses. ${ }^{*}$ Statistically significant at the .10 level; ${ }^{* *}$ at the .05 level (two-tailed test); ${ }^{* * *}$ at the .01 level (two-tailed test). 
Table 6: Predicted ${ }^{a}$ Desired Fertility in West Germany: Men by Age and Education

\begin{tabular}{|c|c|c|c|c|c|c|c|c|}
\hline \multirow[b]{2}{*}{ Variable Name } & \multicolumn{4}{|c|}{ Not Controlling for Children } & \multicolumn{4}{|c|}{ Controlling for Children } \\
\hline & 0 & 1 & 2 & $3,4+$ & 0 & 1 & 2 & $3,4+$ \\
\hline & \multicolumn{8}{|c|}{$\underline{18-35}$ Year Old $(N=3,490)$} \\
\hline Within Sample & 0.082 & 0.104 & 0.620 & 0.194 & 0.082 & 0.104 & 0.620 & 0.194 \\
\hline No HS & 0.158 & 0.141 & 0.504 & 0.197 & 0.171 & 0.170 & 0.488 & 0.171 \\
\hline HS & 0.094 & 0.130 & 0.600 & 0.176 & 0.100 & 0.126 & 0.612 & 0.161 \\
\hline HS+Training & 0.086 & 0.115 & 0.628 & 0.171 & 0.086 & 0.114 & 0.627 & 0.173 \\
\hline College Prep. & 0.089 & 0.070 & 0.636 & 0.206 & 0.089 & 0.073 & 0.637 & 0.202 \\
\hline $\mathrm{CP}+$ Training & 0.070 & 0.093 & 0.623 & 0.214 & 0.066 & 0.097 & 0.625 & 0.212 \\
\hline College & 0.055 & 0.068 & 0.592 & 0.285 & 0.052 & 0.066 & 0.583 & 0.299 \\
\hline
\end{tabular}

\section{6-45 Year Old $(N=1,580)$}

$\begin{array}{llllllllll}\text { Within Sample } & 0.053 & 0.145 & 0.583 & 0.220 & 0.053 & 0.145 & 0.583 & 0.220 \\ \text { No HS } & 0.141 & 0.139 & 0.403 & 0.318 & 0.177 & 0.116 & 0.463 & 0.243 \\ \text { HS } & 0.056 & 0.138 & 0.558 & 0.248 & 0.058 & 0.130 & 0.559 & 0.254 \\ \text { HS+Training } & 0.055 & 0.158 & 0.589 & 0.198 & 0.064 & 0.150 & 0.587 & 0.199 \\ \text { College Prep. } & 0.069 & 0.234 & 0.436 & 0.261 & 0.066 & 0.208 & 0.390 & 0.335 \\ \text { CP+Training } & 0.033 & 0.104 & 0.673 & 0.190 & 0.027 & 0.121 & 0.668 & 0.184 \\ \text { College } & 0.047 & 0.114 & 0.558 & 0.281 & 0.038 & 0.129 & 0.557 & 0.277\end{array}$

46-61 Year Old $(\mathrm{N}=1,843)$

$\begin{array}{lllllllll}\text { Within Sample } & 0.053 & 0.118 & 0.539 & 0.291 & 0.053 & 0.118 & 0.539 & 0.291 \\ \text { No HS } & 0.083 & 0.062 & 0.688 & 0.166 & 0.067 & 0.055 & 0.687 & 0.190 \\ \text { HS } & 0.073 & 0.179 & 0.429 & 0.319 & 0.075 & 0.144 & 0.460 & 0.321 \\ \text { HS+Training } & 0.054 & 0.134 & 0.561 & 0.251 & 0.056 & 0.130 & 0.559 & 0.256 \\ \text { College Prep./ } & 0.055 & 0.061 & 0.562 & 0.322 & 0.041 & 0.073 & 0.572 & 0.314 \\ \text { CP+Training } & & & & & & & & \\ \text { College } & 0.039 & 0.059 & 0.473 & 0.429 & 0.037 & 0.070 & 0.477 & 0.416\end{array}$

Notes: ${ }^{a}$ The predictions by educational attainment are obtained by assuming that all individuals in the sample have the same educational attainment while using the individual data for all other covariates. 
Table 7: Estimated Effect of Education on Desired Fertility in EU 15: Women by Age

\begin{tabular}{|c|c|c|c|c|c|c|c|}
\hline \multirow[b]{2}{*}{ Variable Name } & \multirow[b]{2}{*}{ Fraction } & \multicolumn{3}{|c|}{ Not Controlling for Children } & \multicolumn{3}{|c|}{ Controlling for Children } \\
\hline & & 0 & 1 & $3,4+$ & 0 & 1 & $3,4+$ \\
\hline & & \multicolumn{5}{|c|}{ 18-35 Year Old $(\mathrm{N}=2,669)$} & \\
\hline \multirow{3}{*}{$\begin{array}{l}\text { No Upper Second. (Ref.) } \\
\text { Upper Secondary }\end{array}$} & 35.1 & & & & & & \\
\hline & 29.4 & 0.404 & -0.034 & -0.167 & 0.295 & -0.033 & -0.096 \\
\hline & & $(0.285)$ & $(0.169)$ & $(0.135)$ & $(0.292)$ & $(0.178)$ & $(0.141)$ \\
\hline \multirow[t]{2}{*}{ 1st Stage Tertiary } & 31.7 & 0.434 & -0.162 & 0.190 & 0.245 & -0.237 & $0.283^{* *}$ \\
\hline & & $(0.293)$ & $(0.194)$ & $(0.136)$ & $(0.294)$ & $(0.201)$ & $(0.143)$ \\
\hline \multirow[t]{2}{*}{ 2nd Stage Tertiary } & 3.8 & 0.409 & $-0.913^{*}$ & $\mathbf{0 . 0 3 0}$ & 0.223 & $-0.739^{*}$ & 0.115 \\
\hline & & $(0.561)$ & $(0.493)$ & $(0.274)$ & $(0.548)$ & $(0.434)$ & $(0.300)$ \\
\hline \multirow[t]{2}{*}{$R^{2}$} & & & 0.097 & & & 0.153 & \\
\hline & & \multicolumn{4}{|c|}{ 36-45 Year Old $(N=1,366)$} & & \\
\hline \multirow{3}{*}{$\begin{array}{l}\text { No Upper Second. (Ref.) } \\
\text { Upper Secondary }\end{array}$} & 42.1 & & & & & & \\
\hline & 23.8 & 0.143 & $0.397^{*}$ & $0.355^{* *}$ & 0.217 & 0.400 & $0.479^{* *}$ \\
\hline & & $(0.419)$ & $(0.234)$ & $(0.171)$ & $(0.478)$ & $(0.261)$ & $(0.195)$ \\
\hline \multirow[t]{2}{*}{ 1st Stage Tertiary } & 26.4 & $0.822^{* *}$ & 0.076 & 0.167 & 0.392 & -0.178 & $0.334^{*}$ \\
\hline & & $(0.390)$ & $(0.258)$ & $(0.173)$ & $(0.434)$ & $(0.268)$ & $(0.193)$ \\
\hline \multirow[t]{2}{*}{ 2nd Stage Tertiary } & 7.6 & 0.449 & -0.201 & 0.084 & -0.191 & -0.441 & 0.331 \\
\hline & & $(0.619)$ & $(0.423)$ & $(0.272)$ & $(0.675)$ & $(0.440)$ & $(0.286)$ \\
\hline \multirow[t]{2}{*}{$R^{2}$} & & & 0.103 & & & 0.279 & \\
\hline & & \multicolumn{4}{|c|}{ 46-61 Year Old $(N=1,914)$} & & \\
\hline \multirow{3}{*}{$\begin{array}{l}\text { No Upper Second. (Ref.) } \\
\text { Upper Secondary }\end{array}$} & 56.9 & & & & & & \\
\hline & 18.8 & $-0.660^{*}$ & $-0.551^{* *}$ & -0.037 & $-0.622^{*}$ & $-0.494^{*}$ & 0.162 \\
\hline & & $(0.356)$ & $(0.252)$ & $(0.149)$ & $(0.356)$ & $(0.273)$ & $(0.167)$ \\
\hline \multirow[t]{2}{*}{ 1st Stage Tertiary } & 18.9 & $-0.965^{* *}$ & -0.150 & $0.366^{* *}$ & $-1.322^{* * *}$ & $-0.545^{* *}$ & $\mathbf{0 . 5 8 9} 9^{* * *}$ \\
\hline & & $(0.445)$ & $(0.236)$ & $(0.151)$ & $(0.498)$ & $(0.260)$ & $(0.167)$ \\
\hline \multirow[t]{2}{*}{ 2nd Stage Tertiary } & 5.3 & $-1.215^{*}$ & -0.495 & $\mathbf{0 . 6 0 5} 5^{* *}$ & -1.182 & -0.538 & $0.966^{* * *}$ \\
\hline & & $(0.707)$ & $(0.408)$ & $(0.252)$ & $(0.749)$ & (0.439) & $(0.294)$ \\
\hline$R^{2}$ & & & 0.117 & & & 0.280 & \\
\hline
\end{tabular}

Notes: See the explanation in the text for details on the construction of the education variables. All models also include controls for the EU 15 countries/regions (West Germany, East Germany, Austria, Finland, Denmark, Belgium, Luxembourg, France, Greece, Italy, Spain, Ireland, UK, Netherlands, Portugal, Sweden), political orientation scale, in school, age and partnership measures comparable to the ones used in the analysis for West Germany, labor force status indicators (self employed, employed, not working), location (village or rural, small town, large town or city), a four category adjusted household income scale and controls for 'don't know' (political scale and income) and refusal (political scale and partnership). Robust standard errors are presented in parentheses. ${ }^{*}$ Statistically significant at the .10 level; ${ }^{* *}$ at the .05 level (two-tailed test); ${ }^{* * *}$ at the .01 level (two-tailed test). 


\section{VIENNA INSTITUTE OF DEMOGRAPHY}

\section{Working Papers}

Winkler-Dworak, Maria. 2003. Food Security, Fertility Differentials and Land Degradation in Sub-Saharan Africa: A Dynamic Framework. VID Working Papers 01/2003. Vienna Institute of Demography.

Frejka, Tomas and Jean-Paul Sardon. 2003. Fertility Austria: Past, Present and the Near Future. VID Working Papers 02/2003. Vienna Institute of Demography.

Sanderson, Warren C., Sergei Scherbov, Brian C. O'Neill, and Wolfgang Lutz. 2003. Conditional probabilistic population forecasting. VID Working Papers 03/2003. Vienna: Vienna Institute of Demography.

Fliegenschnee, Katrin, Anne Goujon, and Wolfgang Lutz. 2004. Neue demographische Szenarien zur Zukunft der Evangelischen Kirche in Österreich. VID Working Papers 01/2004. Vienna: Vienna Institute of Demography.

Engelhardt, Henriette. 2004. Fertility Intentions and Preferences: Effects of Structural and Financial Incentives and Constraints in Austria. VID Working Papers 02/2004. Vienna: Vienna Institute of Demography.

Prskawetz, Alexia, Tomas Kögel, Warren C. Sanderson, and Sergei Scherbov. 2004. The Effects of Age Structure on Economic Growth: An Application of Probabilistic Forecasting to India. VID Working Papers 03/2004. Vienna: Vienna Institute of Demography.

Schwarz, Franz. 2004. Analysis of Inequalities in Waiting Time at the Visit to the Physician using Regression Modeling for Duration Data. VID Working Papers 04/2004. Vienna: Vienna Institute of Demography.

Sobotka, Tomáš, Maria Winkler-Dworak, Maria Rita Testa, Wolfgang Lutz, Dimiter Philipov, Henriette Engelhardt, and Richard Gisser. 2005. Monthly Estimates of the Quantum of Fertility: Towards a Fertility Monitoring System in Austria. VID Working Papers 01/2005. Vienna: Vienna Institute of Demography.

Engelhardt, Henriette und Alexia Prskawetz. 2005. Arbeitsmarkt und Demographie VID Working Papers 02/2005. Vienna: Vienna Institute of Demography.

Heiland, Frank, Alexia Prskawetz, and Warren C. Sanderson. 2005. Do the MoreEducated Prefer Smaller Families? VID Working Papers 03/2005. Vienna: Vienna Institute of Demography.

The Vienna Institute of Demography Working Paper Series receives only limited review. Views or opinions expressed herein are entirely those of the authors. 